\title{
Familial Frontotemporal Dementia-Associated Presenilin-1 c.548G > T Mutation Causes Decreased mRNA Expression and Reduced Presenilin Function in Knock-In Mice
}

\author{
Hirotaka Watanabe, ${ }^{1}$ Dan Xia, ${ }^{1,2}$ Takahisa Kanekiyo, ${ }^{3}$ Raymond J. Kelleher III, ${ }^{2,4}$ and Jie Shen ${ }^{1,4}$ \\ ${ }^{1}$ Center for Neurologic Diseases, Department of Neurology, Brigham and Women's Hospital, Boston, Massachusetts 02115, ${ }^{2}$ Center for Human Genetic \\ Research, Department of Neurology, Massachusetts General Hospital, Boston, Massachusetts 02114, ${ }^{3}$ Department of Neuroscience, Mayo Clinic, \\ Jacksonville, Florida 32224, and ${ }^{4}$ Program in Neuroscience, Harvard Medical School, Boston, Massachusetts 02115
}

\begin{abstract}
Mutations in the presenilin-1 (PSEN1) gene are associated with familial Alzheimer's disease and frontotemporal dementia (FTD). Interestingly, neuropathological analysis of a Belgian FTD family carrying a PSEN1 c.548G $>$ T mutation confirmed neurodegeneration in the absence of amyloid plaques. To investigate the impact of the $c .548 G>T$ mutation on presenilin-1 (PS1) function in vivo, we introduced this mutation into the genomic Psen 1 locus. The resulting c.548G $>T$ knock-in (KI) mice are viable but express markedly lower levels of Psen $1 \mathrm{mRNA}$ and protein in the brain. This reduction is due to production of aberrantly spliced transcripts lacking either exon 6 or exons 6 and 7 and their subsequent degradation via non-sense-mediated decay (NMD); inhibition of NMD by cycloheximide treatment stabilized these transcripts and restored the level of Psen $1 \mathrm{mRNA}$ in KI/KI brains. Interestingly, the reduction of Psen $1 \mathrm{mRNA}$ expression and the degradation of aberrant $P$ sen 1 splice products occur exclusively in the brain but not in other tissues. Consistent with decreased Psen 1 expression, $\gamma$-secretase activity was strongly reduced in the cerebral cortex of KI mice, as measured by de novo $\gamma$-secretase-mediated cleavage of APP and Notch. Moreover, PS1 expressed from Psen 1 cDNA carrying the c.548G $>$ T mutation displayed normal $\gamma$-secretase activity in cultured cells, indicating that the corresponding p.183G $>V$ amino acid substitution does not affect $\gamma$-secretase activity. Finally, Psen 1 c.548G $>T^{K I / K I} ;$ Psen $2^{-1-}$ mice exhibited mild spatial memory deficits in the Morris water maze task. Together, our findings demonstrate that the $c .548 \mathrm{G}>T$ mutation results in a brain-specific loss of presenilin function due to decreased $P s e n 1 \mathrm{mRNA}$ expression.
\end{abstract}

\section{Introduction}

Frontotemporal dementia (FTD) is the second most common form of dementia following Alzheimer's disease (AD) (Sjögren and Andersen, 2006). FTD is a clinically diverse syndrome characterized by profound behavioral changes and degeneration of the frontal and anterior temporal cortex (Neary et al., 2005). Due to the clinical and neuropathological heterogeneity, FTD comprises a number of related disorders with overlapping but distinct features, including Pick's disease and frontotemporal lobar degeneration. For example, tau pathology is present in some FTD cases, whereas others lack tau deposition. A large proportion $(\sim 20-50 \%)$ of FTD cases have a familial component, and muta-

\footnotetext{
Received Jan. 20, 2012; accepted Feb. 19, 2012.

Author contributions: H.W., R.J.K., and J.S. designed research; H.W., D.X., and T.K. performed research; H.W. analyzed data; H.W., R.J.K., and J.S. wrote the paper.

This work was supported by National Institutes of Health Grants R01NS041783 and RC2AG036614 (to J.S.) and grants from the Alzheimer's Association (to R.J.K., J.S.). We thank H. Zhao and X. Zou for breeding and genotyping the mice, and other laboratory members for helpful discussions. We also thank T. Iwatsubo and T. Tomita for pTrcHis2A-C100-FmH and pTrcHis2A-N102-FmH plasmids, B. DeStrooper for Psen double-knock-out mouse embryonic fibroblasts, P. Davies for phospho-specific tau antibodies (PHF1 and (P13), and A. Takashima for total tau antibody (J.M.).

The authors declare no competing financial interests.

Correspondence should be addressed to Dr. Jie Shen, Center for Neurologic Diseases, Brigham and Women's Hospital, Program in Neuroscience, Harvard Medical School, 77 Avenue Louis Pasteur, New Research Building 636E, Boston, MA 02115. E-mail: jshen@rics.bwh.harvard.edu.

DOI:10.1523/JNEUROSCI.0317-12.2012

Copyright $\odot 2012$ the authors $\quad 0270-6474 / 12 / 325085-12 \$ 15.00 / 0$
}

tions in microtubule-associated protein tau and progranulin genes are the most frequent genetic causes (Galimberti and Scarpini, 2010). Interestingly, mutations in the presenilin-1 (PSEN1) and PSEN2 genes, which are the major cause of familial AD, have also been implicated in FTD (Mendez and McMurtray, 2006). Since the first identification of the PSEN1 c.338T $>C$ mutation in cases of familial dementia with prominent clinical frontotemporal features (Raux et al., 2000), >10 mutations in the PSEN genes have been associated with clinical diagnoses of FTD, in some cases accompanied by frontotemporal atrophy and frontotemporal hypoperfusion on neuroimaging studies (Rippon et al., 2003; Dermaut et al., 2004; Halliday et al., 2005; Zekanowski et al., 2006; Bernardi et al., 2009; de Bot et al., 2009; Marcon et al., 2009; Gallo et al., 2010; Borroni et al., 2011). Moreover, some pathogenic PSEN1 mutations can cause neuropathological changes consistent with coexisting Pick's disease and AD (Ikeda et al., 1996; Halliday et al., 2005). Interestingly, several of these mutations reside at the exon/intron boundaries and, therefore, may affect PSEN1 splicing in addition to causing mis-sense substitutions (Raux et al., 2000; Dermaut et al., 2004; Borroni et al., 2011). Thus, mutations in PSEN may result in overlapping clinical and neuropathological manifestations of $\mathrm{AD}$ and $\mathrm{FTD}$, and functional changes of presenilin (PS) may underlie common pathogenesis of both dementias.

To investigate how PSEN mutations may be associated with FTD, we chose the PSEN1 c.548G $>$ T mutation, which was 
originally identified in familial FTD patients with neuropathological confirmation of Pick's-type tauopathy in the absence of amyloid deposition (Dermaut et al., 2004). Since the $c .548 G>T$ mutation resides at the last nucleotide of exon 6 , we generated knock-in (KI) mice in which the $c .548 G>T$ mutation was introduced into the genomic Psen 1 locus. The c.548G $>T^{K I / K I}$ mice are viable, but Psen 1 mRNAs are significantly decreased selectively in the brain due to aberrant exon skipping and subsequent degradation of aberrantly spliced transcripts by non-sensemediated mRNA decay. Accordingly, $\gamma$-secretase activity is reduced in the KI brain, as measured by $\gamma$-secretasemediated cleavage of two physiological substrates, Notch and amyloid precursor protein (APP). However, PS1 expressed from full-length Psen 1 c.548G $>$ T mRNA displayed normal $\gamma$-secretase activity when tested in cultured cells. Furthermore, $P \operatorname{sen} 1^{K I / K I} ; P \operatorname{sen} 2^{-/-}$mice exhibited a significant deficit in spatial reference memory. Together, these findings demonstrate that the $c .548 G>T$ mutation causes brain-specific reduction of Psen 1 mRNA expression and PS function in the maintenance of $\gamma$-secretase activity and memory.

\section{Materials and Methods}

Generation of Psen 1 c.548G > T KI mice. For the Psen1 c.548G $>$ T KI construct, a $2.49 \mathrm{~kb}$ leftarm fragment and a $3.15 \mathrm{~kb}$ right-arm fragment surrounding exon 6 were amplified by PCR using BAC (bacterial artificial chromosome) DNA harboring the mouse Psen1 gene (clone RP23-330F11, Children's Hospital Oakland Research Institute) as a template. The primer sequences are $5^{\prime}$-TACCGCGG AATGGGATGTGTGTGTTGGGATGC- ${ }^{\prime}$ and 5'-TGGCGGCCGCATGTGAGAATCCTGGG TGCAGTC- $3^{\prime}$ for the left-arm (the italic sequences are for SacII and NotI, respectively), and 5'-GCGTCGACAAGTATGTGCTGATC CCCAAAGC-3' and 5'-GCAAGCTTAAGT GCTGGGATTACAGGAGGAC-3' for the rightarm (the italic sequences are for SalI and HindIII recognition sites, respectively). The c.548G $>T$ pathogenic mutation (encoding a mis-sense mutation, p.183G $>$ V) and c.546A $>G$ humanized nucleotide change (a silent mutation for Leu at the amino acid residue 182) were introduced by site-directed mutagenesis into exon 6 in the right-arm fragment (see Fig. 1A) (only c.548G $>T$ mutation will be described hereafter). The left- and right-arm fragments were then subcloned into the SacII-NotI site and the SalI-HindIII site of the PGKneolox2DTA plasmid (gift of P. Soriano, Mount Sinai School of Medicine, New York, NY), respectively, to produce the KI targeting vector (Fig. $1 B$ ), which was then confirmed by extensive restriction digestions and sequencing. The linearized targeting
A

exon 6

intron 6

Human WT PSEN1 TTTTTTTCATTCATTTACTTGGg gtaagttgtgaaatttt

FTD (c.548G>T) TTTTTTTCATTCATTTACTTGGT gtaagttgtgaaatttt

Phe Phe Ser Phe lle Tyr Leu Val

c.548G>T KI mouse TTTTTTTCGTTCATTTACTTGGT gtaagtaatacagggtt Phe Phe Ser Phe lle Tyr Leu Val

B
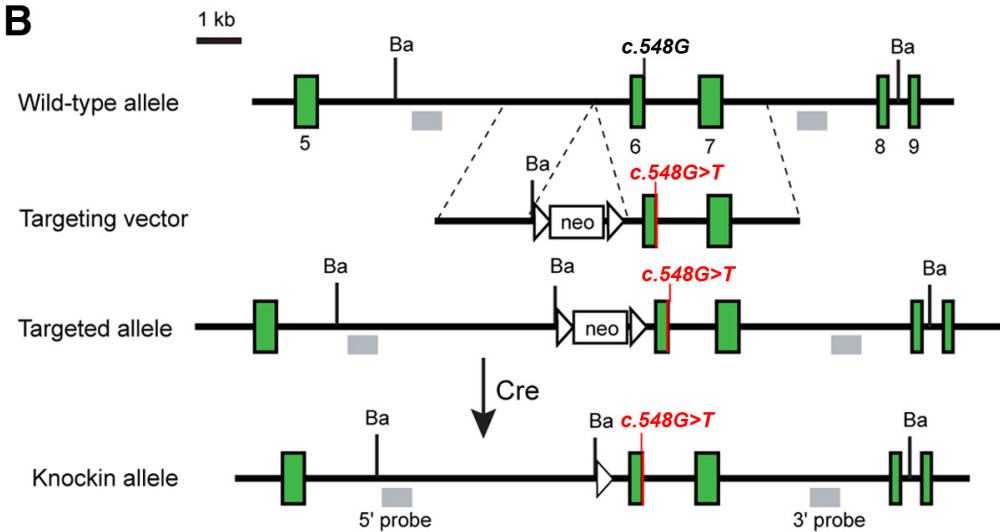

C

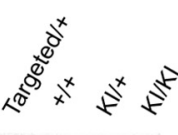

D probe

Wild-type allele : IAC T TAG GIGTAGTAA $\mathrm{kb}$

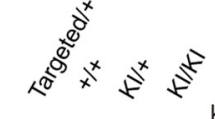
$\mathrm{kb}$
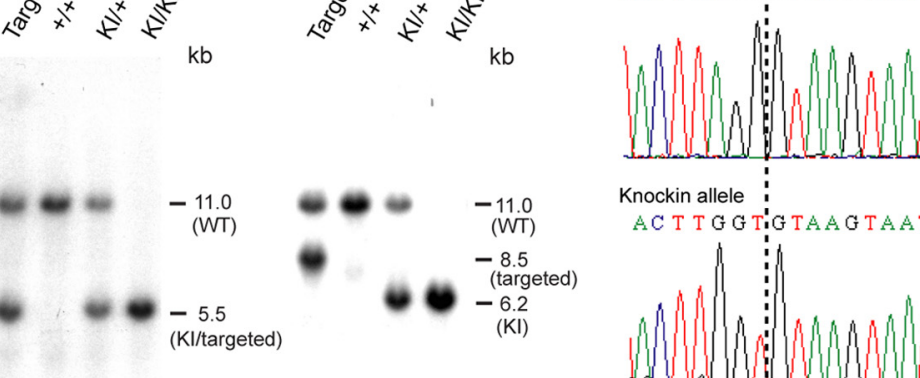

Knockin allele :

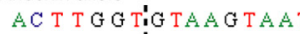

5 ' probe

3' probe

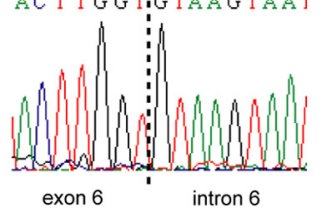

E
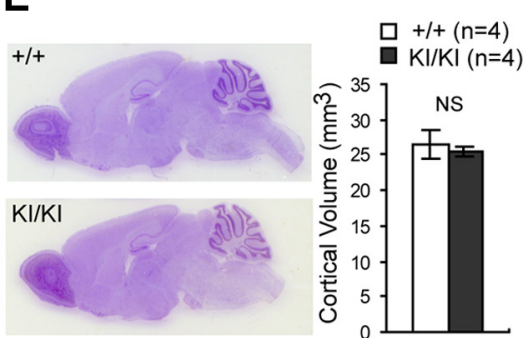

$\mathbf{F}$
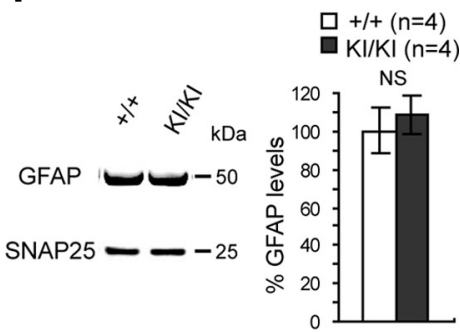

Figure 1. Generation of Psen 1 c.548G $>$ TKI mice. A, Sequence alignment at the boundary of PSEN1 exon 6 and intron 6, where the $c .548 \mathrm{G}>T$ mutation resides, among human wild-type and FTD (c.548G $>T)$ as well as mouse $\mathrm{KI}(c .548 \mathrm{G}>T)$ alleles. The nucleotides and amino acid residues in red indicate the $c .548 \mathrm{G}>T$ mutation and the subsequent p.183G $>\mathrm{V}$ alteration in FTD patients and KI mice. $\boldsymbol{B}$, Targeting strategy for the generation of $c .548 \mathrm{G}>$ T KI mice. The green boxes represent $P$ sen 1 exons 5-9. The c.548G $>$ T mutation is located at the last nucleotide of exon 6. Ba, BamHI. C, Southern analysis of tail genomic DNAs from mice carrying either the targeted allele (after homologous recombination but before Cre-mediated site-specific recombination to remove the floxed PGK-neo cassette) or the KI allele (after the removal of the floxed PGK-neo cassette) using the $5^{\prime}$ or $3^{\prime}$ external probe. Tail genomic DNAs were digested with BamHI. The $11.0 \mathrm{~kb}$ recognized by either the $5^{\prime}$ or the $3^{\prime}$ external probe represents the wild-type allele, whereas the $5.5 \mathrm{~kb}$ fragment recognized by the $5^{\prime}$ external probe represents the targeted or the $\mathrm{KI}$ allele. The $3^{\prime}$ external probe gives rise to 8.5 and $6.2 \mathrm{~kb}$ fragments, which represent the targeted and KI alleles, respectively. D, Sequencing of $\mathrm{PCR}$ products from c.548G $>T \mathrm{KI} / \mathrm{KI}$ genomic tail DNAs confirms the correct introduction of the $c .548 \mathrm{G}>T \mathrm{KI}$ mutation. $\boldsymbol{E}$, Nissl staining of sagittal brain sections of $c .548 G>T^{K I / K I}$ and littermate wild-type mice shows similar brain morphology. Stereological assessment of cortical volume using a series of $10 \mu \mathrm{m}$ sagittal sections from $\mathrm{KI} / \mathrm{KI}$ and wild-type $(+/+)$ littermate mice at $\sim 2$ years of age ( $n=4$ per genotype) reveals similar cortical volume between the two genotypic groups. The representative comparable sections are shown. $\boldsymbol{F}$, Western analysis shows similar GFAP signals in the brain of KI/KI and control mice at 12-20 months of age. NS, Not significant. 
A

$$
\begin{aligned}
& 1 \mathrm{~d} \quad 1 \mathrm{~m} \quad 10 \mathrm{~m}
\end{aligned}
$$

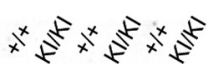

$\mathrm{kb}$

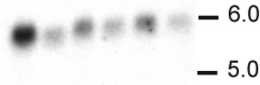

$-5.0$

$-4.0$

\section{Psen1 mRNAs}

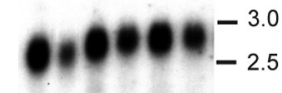

GAPDH mRNAs

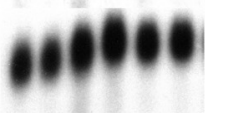

B
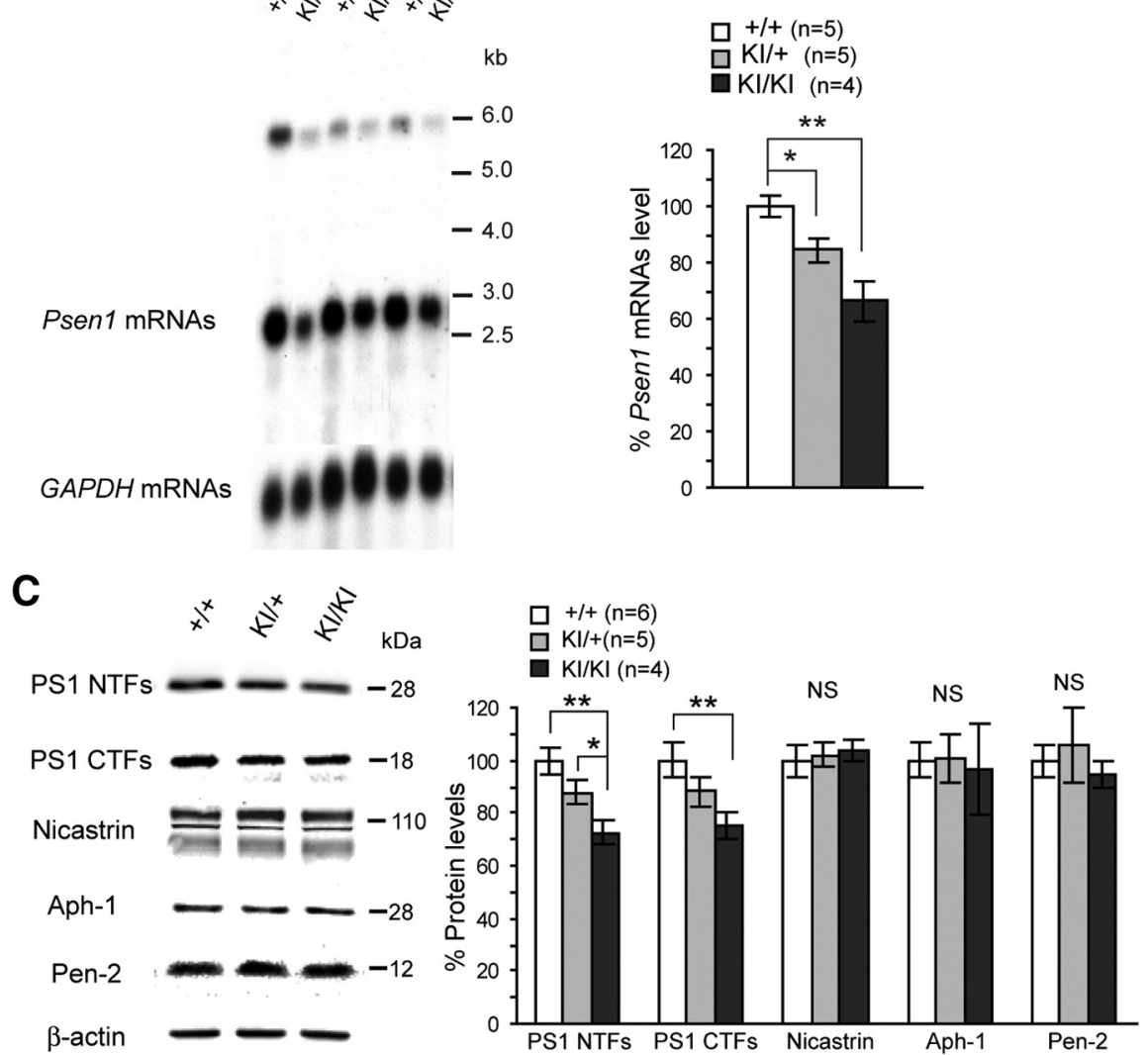

Figure 2. Levels of Psen $1 \mathrm{mRNAs}$ and proteins are reduced in the brain of c.548G $>$ TKI mice. $A$, Northern blotting of total RNAs from KI/KI and littermate control brains shows remarkable reduction in $P \operatorname{sen} 1 \mathrm{mRNAs}$ and pre-mRNAs in c.548G $>K^{\mathrm{K} / \mathrm{Kl}}$ brains at all ages examined, and the reduction appears most dramatic at postnatal day 1. B, qRT-PCR analysis of Psen $1 \mathrm{mRNAs}$ in the cortices of $\mathrm{KI} / \mathrm{KI}, \mathrm{KI} /+$, and littermate controls at 2 months of age. The levels of Psen $1 \mathrm{mRNAs}$ are decreased depending on the Kl allele dosage ( $n \geq 4$ per genotype), with $\sim 40 \%$ reduction in KI/KI. C, Effects of the $.548 \mathrm{G}>T$ mutation on levels of $\gamma$-secretase complex proteins. Western analysis shows $\sim 30 \%$ decreases of PS1 NTFs and CTFs in c.548G $>T^{K / / K I}$ brains at 2 months of age $(n \geq 4$ per genotype). In contrast, other components (nicastrin, Aph-1, and Pen-2) are present at comparable levels between the genotypic groups. ${ }^{*} p<0.05 ;{ }^{* *} p<0.01$. NS, Not significant. All data are expressed as mean \pm SEM.

vector by XhoI was electroporated into MKV6.5 ES cells (gift of R. Jaenisch, Whitehead Institute, Cambridge, MA) and selected with $150 \mu \mathrm{g} / \mathrm{ml} \mathrm{G418}$ (Invitrogen) for 4-5 d. Genomic DNAs were purified from a total of 360 independent ES clones and were subjected to Southern analysis using the $5^{\prime}$ probe. For Southern analysis, genomic DNAs were digested with BamHI. Among 52 clones that tested positive for proper homologous recombination in the 5' arm, 3 ES clones (3-9-H, 4-1-F, 7-11-A) were expanded and subjected to further Southern analysis using the $5^{\prime}, 3^{\prime}$, and neomycin probes (Fig. $1 B$ ). We confirmed that homologous recombination correctly occurred in both the $5^{\prime}$ and $3^{\prime}$ homologous regions in these three clones. To generate Psen 1 c.548G $>$ T KI mice, the targeted ES cells (clones 4-1-F and 7-11-A) were injected into C57BL/6 blastocysts, and the resulting male chimeric mice were mated with C57BL/6J-129 F1 mice. Mice transmitting the targeted allele were further crossed to $\alpha$ CaMKII-Cre male transgenic mice (Yu et al., 2001) to excise the floxed phosphoglycerate-kinase-neomycin (PGKneo) cassette, as the $\alpha$ CaMKII promoter allows the Cre transgene to express weakly in male germ cells (Ignotz and Suarez, 2005). The resulting progeny (KI heterozygous mice) were intercrossed to obtain homozygous KI mice for further characterization. Correct homologous and Cre-mediated sitespecific recombination events were further confirmed by Southern analysis with tail genomic DNAs using the external 5', 3', and neo probes, and by sequencing to detect the presence of the $c .548 G>T$ mutation in genomic DNAs. Since offspring from both targeted ES clones 4-1-F and 7-11-A were indistinguishable, we used the KI mice derived from the ES clone 4-1-F for further characterization. In subsequent generations, mice were genotyped routinely by PCR, and the $c .548 G>T$ KI allele was detected by size shift due to the remaining loxP and construct sequence between exons 5 and 6 using the following primers: 5'-TGGTGAGAGCTCAGCAGGTAAG-3' and 5'-TGCTTTCTAGTTGTCCTTCGTCG-3'. The $410 \mathrm{bp}$ band represents the wild-type allele, whereas the 529 bp band represents the $\mathrm{KI}$ allele. Psen 1 c.548G $>T^{K I / K I} ;$ Psen $2^{-1-}$ mice were generated by breeding Psen 1 c.548G $>$ T KI mice with Psen $2^{-1-}$ mice, which exhibited no detectable phenotypes (Steiner et al., 1999). The genetic background of all the mice used in this study was C57BL/6J 129 F1 hybrid. All procedures relating to animal care and treatment conformed to the institutional and $\mathrm{NIH}$ guidelines.

$q R T-P C R$ and Northern analyses. Total RNAs were purified with TRI reagent (Sigma) according to manufacturer's protocol, treated with DNase I, and reverse transcribed in the presence of random hexamers and SuperScript III Reverse Transcriptase (Invitrogen). PCRs were performed using SYBR Green PCR Master Mix with a 7500 Fast Real-Time PCR System (Applied Biosystems) using cDNA and gene-specific primers. Reactions were performed in triplicate, and threshold cycle values were normalized to those of Gapdh. The primer pairs used in this study were as follows: 5' -TGGCCACCATCAAATCAG- ${ }^{\prime}$ ' and 5' $^{\prime}$-TC ATGATGGCCGCATTCAG-3' for Psen1; and 5'-TTGTCTCCTGCGACTTCA-3' and $5^{\prime}$ TCCACCACCCTGTTGCTGTA-3' for Gapdh. These primer pairs were confirmed not to give rise to primer dimers during the PCR. For Northern analysis, $10-20 \mu \mathrm{g}$ of total RNA was separated in formaldehyde agarose gels and transferred to nylon membranes (GE Healthcare). Hybridization was performed using $[\alpha-$ $\left.{ }^{32} \mathrm{P}\right]$ dCTP-labeled probes specific for each gene. Almost the entire coding region of the mouse Psen1 gene was used for a Psen1-specific probe so as to detect any possible transcriptional/posttranscriptional variant from the Psen 1 gene.

Western analysis. Dissected cortices (at 1-2 months for c.548G $>T$ KI mice) were homogenized in RIPA buffer [50 mm Tris-Cl, pH 7.6, $150 \mathrm{~mm}$ $\mathrm{NaCl}, 0.5$ mm EDTA, 1\% NP40, 0.5\% sodium deoxycholate, $0.1 \%$ SDS, protease inhibitor cocktail (Sigma), $1 \mathrm{~mm}$ PMSF]. Equal amounts (10-40 $\mu$ g per lane) of proteins were separated in NuPAGE gels (Invitrogen) and transferred to nitrocellulose membranes. The membranes were blocked in 5\% nonfat milk/TBS for $1 \mathrm{~h}$ and incubated with specific primary antibodies as follows: rabbit anti-PS1 N-terminal fragments (NTFs; catalog \#529591, Calbiochem); rabbit anti-PS1 C-terminal fragments (CTFs; catalog \#529592, Calbiochem); rabbit anti-Pen2 (catalog \#36-7100, Zymed); rabbit anti-nicastrin (NCT; N1660, Sigma); rabbit anti-Aph1 (PA1-2010, Thermo science); mouse anti- $\alpha$-tubulin (T6199, Sigma); mouse anti-phospho-tau (PHF1 and CP13, gift of P. Davies, Albert Einstein College of Medicine, New York, NY); rabbit anti-total tau (JM, gift of A. Takashima, RIKEN, Saitama, Japan); rabbit anti-Notch1 (V1744) (catalog \#2421, Cell Signal Tech); and mouse anti-SNAP25 (MAB331, Millipore Bioscience Research Reagents). The membrane was then incubated with IRDye $800 \mathrm{CW}$ or IRDye 680-labeled secondary antibodies (LI-COR Bioscience). Signals were developed and quantified with an Odyssey Infrared Imaging System (LI-COR Bioscience).

Administration of cycloheximide. Drug administration was performed as described previously (Contet et al., 2007). Briefly, cycloheximide (Sigma) or saline was intraperitoneally administered at $1 \mathrm{~h}$ intervals (200 
$\mathrm{mg} / \mathrm{kg}$ body weight). Tissues were dissected and frozen for further molecular analysis $4 \mathrm{~h}$ after the first injection.

Cell-based $\gamma$-secretase assay. Psen-deficient mouse embryonic fibroblasts (MEFs) were transfected with equal amounts (1 ng) of expression vectors encoding wild-type or various mutant PS1 along with an N-terminally truncated Notch 1 construct $(\mathrm{N} \Delta \mathrm{E}$, gift of A. Goate, Washington University School of Medicine, St. Louis, MO) as described previously (Heilig et al., 2010). The amount of plasmid DNA used was derived from a dose-curve analysis using $0.125,0.25,0.5,1.0,2.0,4.0$, and $8.0 \mathrm{ng}$ of Psen 1 wild-type cDNAs, and doses within the linear range were $0.5(0.5 \times), 1.0(1 \times)$ and $2.0(2 \times)$ ng. A $1.7 \mathrm{~kb}$ mouse $P$ sen 1 coding sequence was amplified with primers $5^{\prime}$-GATCTCGAGTTC GAGGTCTTTAGGCAGCTTG-3' and 5'-AG TGCGGCCGCTGCTGCAGCGATGGATGTT GG-3' (italics indicates XhoI and NotI sequences, respectively), and subcloned into XhoI-NotI sites of pCI expression vector (Invitrogen). The corresponding mutations of each mutant PS1 were introduced by either subcloning or site-directed mutagenesis. Cells were harvested with RIPA buffer $24 \mathrm{~h}$ after transfection, and Western analysis was performed using anti-Notch1 (V1744) antibody (catalog \#2421, Cell Signal Tech). Data are normalized to $\alpha$-tubulin, and three independent experiments were quantified.

In vitro $\gamma$-secretase assay. $\gamma$-Secretasemediated de novo amyloid- $\beta(\mathrm{A} \beta)$ generation was measured using a method described previously (Takahashi et al., 2003). Briefly, the cortices at 1-2 months of age were homogenized in homogenization buffer ( $20 \mathrm{~mm}$ PIPES, pH 7.0, $140 \mathrm{~mm} \mathrm{KCl}, 0.25 \mathrm{M}$ sucrose, 5 mm EGTA) using a glass/Teflon tissue grinder. The homogenates were centrifuged at $800 \times g$ for $10 \mathrm{~min}$ to remove nuclei and cell debris. The postnuclear supernatants were recentrifuged at $100,000 \times g$ for $1 \mathrm{~h}$, and the resulting pellets were washed with $0.1 \mathrm{M}$ sodium carbonate, $\mathrm{pH} 11.4$, and then centrifuged again. The membrane pellets were solubilized with $1 \%$ 3-[(3-cholamidopropyl) dimethylammonio]-2-hydroxy-1-

propanesulfonate (CHAPSO) in homogenization buffer for $1 \mathrm{~h}$ on ice and then centrifuged at $100,000 \times g$ for $1 \mathrm{~h}$, and finally the resulting sol-

uble fractions were saved at $-80^{\circ} \mathrm{C}$ until used as crude $\gamma$-secretase fractions. For in vitro $\gamma$-secretase assay, the CHAPSO-soluble microsomal proteins were mixed with assay buffer [10 mM HEPES, pH 7.3, $150 \mathrm{~mm} \mathrm{NaCl}, 1 \mathrm{~mm}$ EDTA, complete protease inhibitor cocktail (Roche), $5 \mathrm{~mm} \mathrm{1,10-}$ phenanthroline, $5 \mathrm{mg} / \mathrm{ml}$ phosphoramidon, and $0.1 \%(\mathrm{w} / \mathrm{v})$ phosphatidylcholine], and incubated with recombinant C100-FmH or N102-FmH (1-2 $\mu \mathrm{M})$ as a $\gamma$-secretase substrate at $37^{\circ} \mathrm{C}$ for $14 \mathrm{~h}$. To quantify de novo $\mathrm{A} \beta$ generation, samples were subjected to ELISA specific for $A \beta 40$ and $A \beta 42$. Specific $\gamma$-secretase activity was obtained by subtracting the values obtained from a reaction conducted in the presence of $\gamma$-secretase inhibitor (III-31C, Sigma). For Western analysis of in vitro $\gamma$-secretase assay, specific signals of cleaved substrate were normalized by the signals of SNAP25. For recombinant C100-FmH and N102-FmH, which are tagged with Flag-Myc-Histidine, bacterial strain $\mathrm{DH} 5 \alpha$ was transformed with pTrcHis2A-C100-FmH and pTrcHis2A-N102FmH plasmids (gifts of T. Iwatsubo and T. Tomita, University of Tokyo, Tokyo, Japan), respectively, and induced with $0.1 \mathrm{~mm}$ Isopropyl $\beta$-D-1-thiogalactopyranoside for $3 \mathrm{~h}$. Each recombinant protein was purified with $\mathrm{Ni}^{2+}$-chelated HiTrap Chelating HP column (GE Healthcare).

ELISA. Monoclonal antibodies directed against the $\mathrm{C}$ terminus of $\mathrm{A} \beta 40$ (11A50-B10, Covance) or A $\beta 42$ (12F4, Covance) were used for specific capture of $A \beta$ species. A biotinylated monoclonal secondary antibody ( $4 \mathrm{G} 8$, Covance) recognizing $A \beta$ residues $17-24$ was used for detection of both $\mathrm{A} \beta \mathrm{x}-40$ and $\mathrm{A} \beta \mathrm{x}-42$ with a reporter system of streptavidin-conjugated alkaline phosphatase (Promega) and AttoPhos reagent (Promega). Fluorescence was measured with excitation at $444 \mathrm{~nm}$ and emission at $555 \mathrm{~nm}$ by a Synergy HT microplate reader (BioTek). $\mathrm{A} \beta 40$ and $\mathrm{A} \beta 42$ synthetic peptide standards (BioPeptide) were included in each analysis for quantifying A $\beta$ levels, which were expressed as the picomolar concentration of $A \beta x-40$ or $\mathrm{A} \beta \mathrm{x}-42$. For endogenous mouse $\mathrm{A} \beta$ ELISA, mouse cortices were homogenized in $0.2 \%$ diethylamine and centrifuged at $100,000 \times g$. The resulting supernatants were neutralized with Tris- $\mathrm{Cl}, \mathrm{pH} 6.8$, and directly used for $A \beta$ measurement. Monoclonal antibodies were used for capture of $A \beta 40$ (266) and $A \beta 42$ (21F12), and biotinylated mono- 


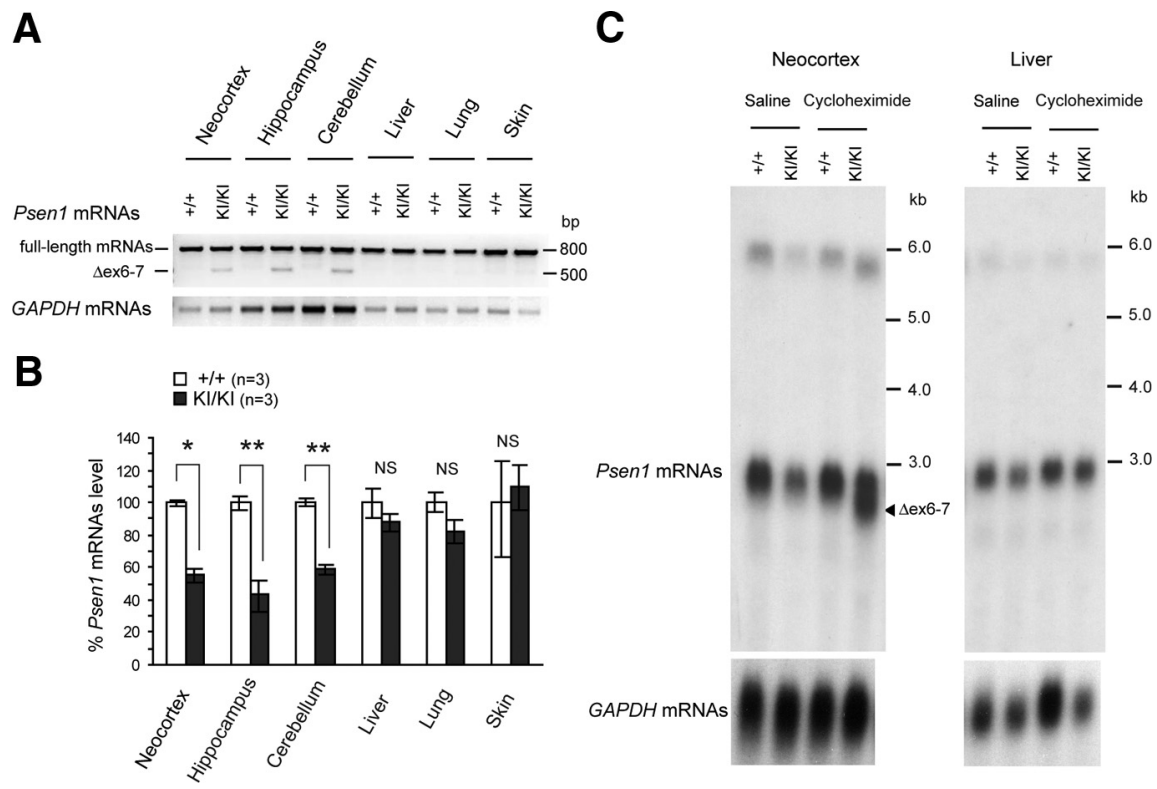

Figure 4. The splicing defects of $P$ sen 1 transcripts in c.548G $>T^{K I / K I}$ mice are brain specific. $A, R T-P C R$ analysis using primers in exons 4 and 10 shows that aberrantly spliced Psen 1 mRNAs ( $\Delta$ ex6 -7, 495 bp) are detected only in brain tissues but not in the liver, lung or skin. $\boldsymbol{B}$, Real-time qRT-PCR analysis using primers in exons 4 and 5 shows that levels of Psen 1 mRNAs are significantly reduced in the neocortex, hippocampus, and cerebellum of $c .548 \mathrm{G}>T^{K I / K I}$ mice, but not in the liver, lung, and skin. C, Cycloheximide treatment reveals the presence of the aberrantly spliced Psen 1 mRNAs in the brain. Northern analysis shows that cycloheximide treatment induces the appearance of the aberrantly spliced Psen 1 mRNAs (arrowhead, $\Delta$ ex6-7), which are smaller in size than the full-length Psen 1 mRNAs $(\sim 2.8 \mathrm{~kb})$, and this occurs only in the brain but not in the liver. ${ }^{*} p<0.05,{ }^{* *} p<0.01$. NS, Not significant. All data are expressed as mean \pm SEM.

clonal secondary antibodies were used for detection of A $\beta 40$ (2G3) and $A \beta 42$ (266). Endogenous $A \beta$ concentration was calculated to divide the total $\mathrm{A} \beta$ amount by the total protein amount in the cortex fraction.

Behavioral analysis. The Morris water maze is a circular pool $160 \mathrm{~cm}$ in diameter. Mice were housed in a standard $12 \mathrm{~h}$ light/dark cycle. Before testing, the experimenter handles each mouse for $5 \mathrm{~min} / \mathrm{d}$ for $5 \mathrm{~d}$. During the hidden platform training, the platform ( $10 \mathrm{~cm}$ in diameter) was kept submerged under water and maintained in the same position. Each mouse was given four trials daily with a maximum duration of $90 \mathrm{~s}$ separated by a minimum of $15 \mathrm{~min}$. If the mouse did not find the hidden platform, it was guided to the platform and allowed to remain on it for $15 \mathrm{~s}$. The swimming of the mice was monitored using an automated tracking system (HVS Image). A group of mice aged 6-8 months (Psen 1 c.548G $>T^{K I / K I} ; P \operatorname{sen} 2^{-/-}$and Psen $\left.1^{+/+} ; P \operatorname{sen} 2^{-/-}\right)$or $18-20$ months ( $P$ sen 1 c.548G $>T^{K I / K I}$ and $P \operatorname{sen} 1^{+/+}$) were trained in the hidden platform task for $12 \mathrm{~d}$. Twenty-four hours after the last training (day 12), the hidden platform was removed and a $90 \mathrm{~s}$ probe trial was performed to test a spatial reference memory. The mice were released from all four quadrants in a pseudorandom manner during the training and the probe trial. Finally, the visible cue task with four trials was performed to verify visual and swimming ability using the platform marked by a yellow object. The experimenters were blind to the genotypes of the mice.

Histological analysis. Brains were perfused with PBS, fixed in 4\% paraformaldehyde for $3 \mathrm{~h}$ at $4^{\circ} \mathrm{C}$, and processed for paraffin embedding. Paraffin-embedded sagittal sections were serially cut at $10 \mu \mathrm{m}$. Sections in every 40 slides were deparaffinized, dehydrated, and stained with $0.5 \%$ Cresyl Violet (Sigma), and analyzed for brain volumes by BioQuant image analysis software. For immunohistochemistry, paraffin-embedded brain sections were deparaffinized, alcohol dehydrated, and immunostained with monoclonal antibodies raised against phosphorylated (pSer396/pSer404) tau (PHF1, gift of P. Davies, Albert Einstein College of Medicine, New York, NY). After specific signals were developed by Vectastain Elite $\mathrm{ABC}$ kit and $\mathrm{DAB}$ peroxidase substrate, the sections were lightly counterstained with hematoxylin. The signals were analyzed using a BX50 microscope system (Olympus).
Data analysis. Statistical analyses were performed using one-way ANOVA or two-tailed unpaired Student's $t$ test for all the comparisons in the behavioral and biochemical results. A $p$ value of $<0.05$ was considered significant. All the data were described as mean \pm SEM.

\section{Results}

Generation of Psen 1 c.548G $>$ T KI mice To investigate the pathogenic mechanism underlying the Psen 1 c.548G $>$ T mutation, we generated a KI mouse in which the $c .548 G>T$ mutation was introduced into Psen 1 exon 6 by homologous recombination. The targeting vector includes the $5^{\prime}$ homologous region $(2.49 \mathrm{~kb})$, floxed PGK-neo cassette and the $3^{\prime}$ homologous region $(3.15 \mathrm{~kb})$, in which the c.548G $>T$ mutation was introduced into the last nucleotide of exon 6 (Fig. $1 A, B$ ). The ES cells carrying the proper homologous recombination events in the $5^{\prime}$ and 3' homologous regions were confirmed by Southern analysis using the $5^{\prime}$ and $3^{\prime}$ external probes, respectively (Fig. $1 B$; data not shown), and were injected into mouse blastocysts to generate chimeric mice, which were then used to generate heterozygous mice carrying the targeted allele (targeted/+). Southern analysis of tail genomic DNAs of these mice confirmed that homologous recombination and germline transmission occurred correctly, as demonstrated by the presence of two bands representing the wild-type allele ( $11.0 \mathrm{~kb}$ for both $5^{\prime}$ and $3^{\prime}$ external probes) and the targeted allele $\left(5.5 \mathrm{~kb}\right.$ for the $5^{\prime}$ external probe, $8.5 \mathrm{~kb}$ for the $3^{\prime}$ external probe) (Fig. $1 C$ ). The floxed PGK-neo selection cassette was removed by crossing the F1 mice transmitted with the targeted allele to Cre-expressing transgenic mice so as to avoid its possible transcriptional interference on Psen1 expression (Fig. 1B). Southern analysis of tail genomic DNAs from the resulting mice confirmed the deletion of the floxed PGK-neo selection cassette using the $3^{\prime}$ external probe (Fig. 1C). The targeted allele following the removal of the floxed $P G K$-neo cassette is termed the KI allele (Fig. $1 B, C$ ). Additional Southern analysis using the neo probe further confirmed the lack of the floxed PGK-neo cassette as well as the absence of random insertion of the targeting vector in the KI mice (data not shown). The correct introduction of the c.548G $>T$ mutation was also confirmed by sequencing (Fig. $1 D$ ).

The c.548G $>T^{K I / K I}$ homozygous mice were born in Mendelian ratio and were fertile, and adult KI/KI mice were grossly normal in appearance compared with littermate controls. Histological analysis of brain morphology shows that $\mathrm{KI} / \mathrm{KI}$ brains were indistinguishable from littermate controls (Fig. $1 E)$. Using stereological methods, we measured cortical volume in Nissl-stained series sagittal sections and found similar cortical volumes between KI/KI and littermate controls even at 20 months of age (Fig. 1E). Western analysis of GFAP, which is elevated accompanying astrogliosis (Beglopoulos et al., 2004; Saura et al., 2004), indicated no increases in the cerebral cortex of KI/KI mice at 12-20 months of age (Fig. 1 F). These results suggest that $P \operatorname{sen} 1 \quad$ c.548G $>T^{K I / K I}$ mice do not develop age-dependent neurodegeneration. 
Levels of Psen $1 \mathrm{mRNAs}$ and proteins are reduced in $c .548 G>T \mathrm{KI}$ mice Since the $c .548 G>T$ mutation resides on the splice junction of exon 6 and intron 6 , which likely disrupts normal splicing of its transcripts, we evaluated Psen 1 mRNA expression in $c .548 G>T$ KI mice. Northern analysis revealed that levels of Psen1 mRNAs are significantly reduced in the cerebral cortex of KI/KI mice throughout their life (from postnatal day 1 to 10 months) (Fig. 2A). qRT-PCR also confirmed the reduction of Psen 1 mRNAs in c.548G $>T$ KI mice in a KI allele dosedependent manner, with a $\sim 40 \%$ reduction in KI/KI mice (Fig. 2B). Western analysis disclosed $\sim 30 \%$ reduction in levels of PS1 NTFs and CTFs in total cortical lysates (Fig. 2C). Given that levels of Psen 1 mRNAs correlated with levels of PS1 proteins in Psen $1^{-1-}$ and Psen $1^{+/-}$mice (Shen et al., 1997), the discrepancy in the reduction of Psen 1 mRNAs $(\sim 40 \%)$ and proteins $(\sim 30 \%)$ in $c .548 G>T^{K I / K I}$ mice may reflect a mechanism suggested in a previous report (Lee et al., 1997), in which mutant PS1 tends to accumulate in transgenic mouse brains. In contrast, the protein levels of other $\gamma$-secretase complex components-NCT, Aph-1, and Pen-2were similar among the three genotypic groups (Fig. 2C).

\section{The presence of aberrant Psen 1 splice} products in $c .548 G>T \mathrm{KI}$ mice and their degradation by non-sense-mediated decay

We next investigated the mechanism underlying reduced levels of Psen 1 mRNAs in the brain of KI/KI mice. The location of the G-to- $\mathrm{T}$ transversion responsible for the $c .548 G>T$ mutation suggested that splicing of Psen 1 transcripts might be disturbed in $\mathrm{KI} / \mathrm{KI}$ mice (Fig. $1 A$ ), because proper splicing requires the exon-intron junction to conform to the consensus sequences (Cartegni et al., 2002). Indeed, RT-PCR using primers in exons 4 and 10 followed by sequencing showed that in addition to normal splice products containing all exons 4-10, two aberrant splice products lacking either exon 6 or exons 6 and 7 were produced in $c .548 G>T^{K I / K I}$ brains (Fig. $3 A$ ). Since the skipping of exon 6 or both exons 6 and 7 results in frame shift and the use of downstream premature termination codons that are normally out of frame, we then evaluated whether these abnormal transcripts are degraded by NMD mechanisms, which constitute a surveillance system to prevent production of truncated proteins (Cartegni et al., 2002). We used cycloheximide, a potent inhibitor of protein synthesis and non-sensemediated decay, to determine whether blockade of NMD would restore the levels of aberrant splice products that are normally
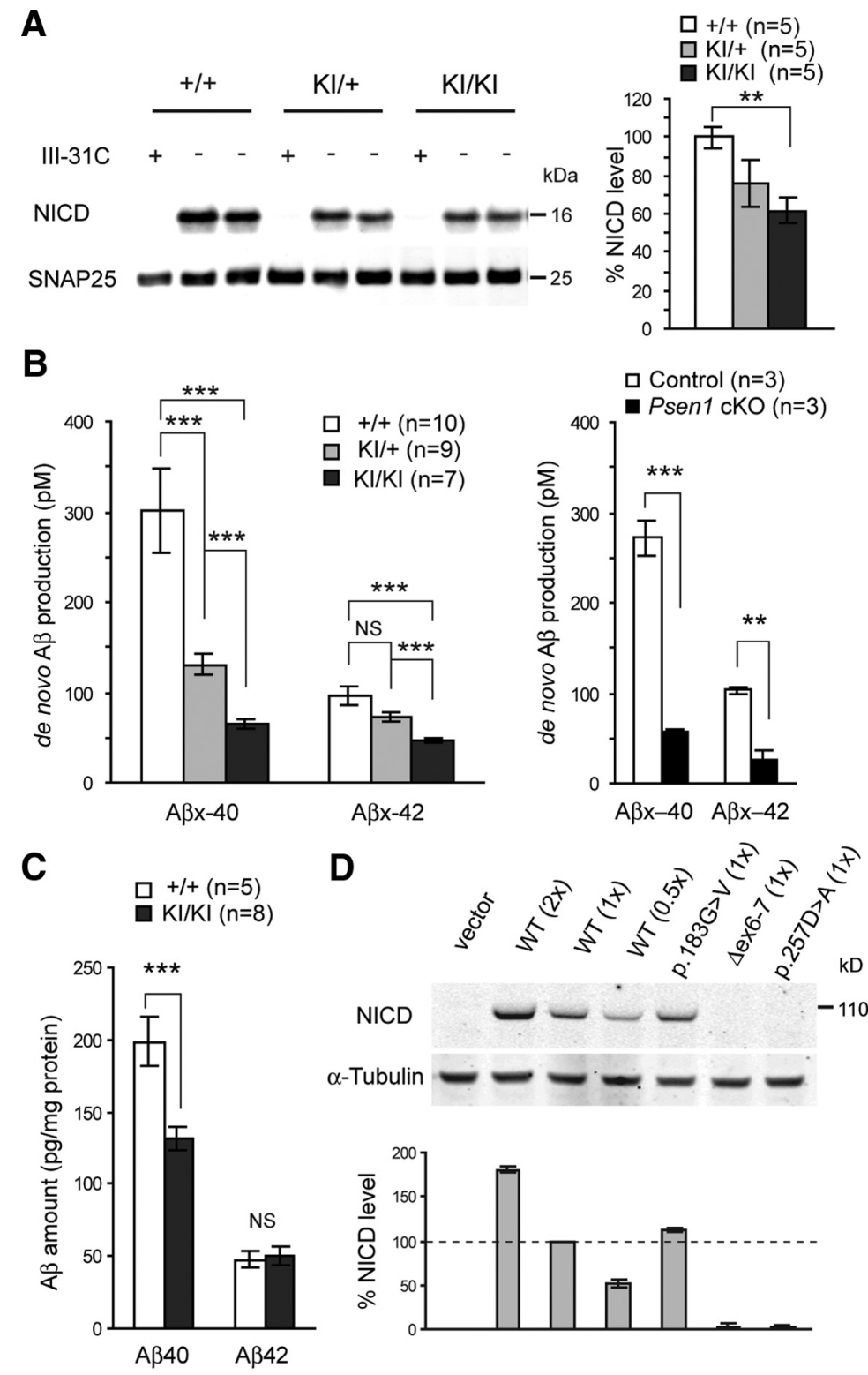

Figure 5. The p.183G $>\mathrm{V}$ alteration does not affect $\gamma$-secretase activity per se but c.548G $>T^{K / / K I}$ mice exhibit reduced $\gamma$-secretase activity. $\boldsymbol{A}$, In vitro $\gamma$-secretase assay using CHAPS0-solubilized cortical fractions and recombinant N102-FmH (substrates of NICD) followed by Western analysis reveals significant reductions of NICD production in $\mathrm{KI} / \mathrm{KI}$ and $\mathrm{KI} /+$ cortices. III-31C is a $\gamma$-secretase inhibitor, which completely abolishes NICD production. SNAP25 is used as internal loading controls of membrane fraction. $\boldsymbol{B}$, Left, In vitro $\gamma$-secretase assay using CHAPSO-solubilized cortical fractions at 2-3 months of age and recombinant C100-FmH (substrates of $A \beta$ peptides) displays a marked reduction in de novo production of $A \beta x-40$ and $A \beta x-42$ peptides ( $n \geq$ 7) in $\mathrm{KI} / \mathrm{KI}$ and $\mathrm{KI} /+$ mice. Right, In vitro $\gamma$-secretase assay using CHAPSO-solubilized cortical fractions from Psen $1 \mathrm{cKO}$ mice $(n=$ 3) shows a marked reduction of de novo production of both $A \beta x-40$ and $A \beta x-42$ peptides. $C$, Sandwich ELISA measurement of endogenous $A \beta$ peptides reveals a significant decrease of $A \beta 40$ but not $A \beta 42$ in the cerebral cortex of $c .548 G>T^{K I / K I}$ mice at $\sim 12$ months of age $(n \geq 5)$. D, Psen 1 wild-type (WT) and p.183G $>V$ cDNAs support comparable levels of $\gamma$-secretase activity as measured by NICD production in Psen-deficient MEFs transfected with either varying amounts of $P$ sen 1 wild-type $(1 \times, 2 \times, 0.5 \times$ WT) or equal amounts $(1 \times)$ of mutant cDNAs (p.183G $>$ V, $\Delta$ ex6 -7 , or p.257D $>$ A) along with N $\Delta E$ cDNAs (encoding substrates of NICD). ${ }^{* *} p<0.01,{ }^{* *} p<0.001$. NS, Not significant. All data are expressed as mean \pm SEM.

degraded by NMD. Indeed, cycloheximide treatment enhanced the stability of the aberrantly spliced transcripts and drastically increased levels of the splice product lacking exons 6 and 7 in KI/KI brains (Fig. 3B). Quantitative RT-PCR analysis also showed that cycloheximide treatment fully rescued the reduction of Psen 1 mRNA levels in KI/KI brains (Fig. 3C). These results reveal that in addition to the glycine-to-valine conversion at the amino acid residue 183 (p.183G $>\mathrm{V}$ ), the $c .548 \mathrm{G}>\mathrm{T}$ mutation 

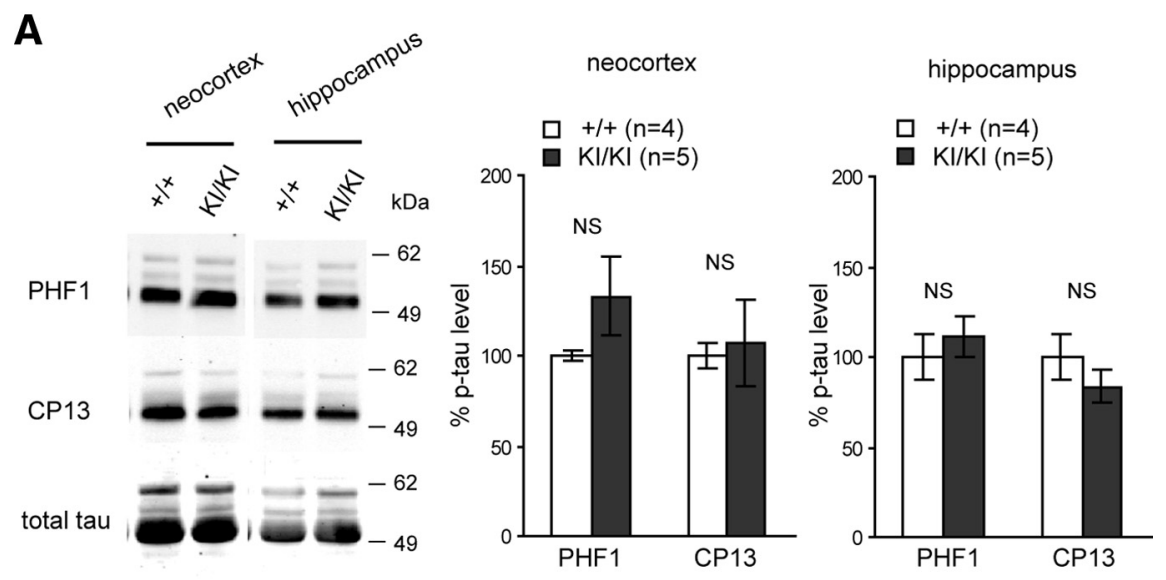

\section{B}

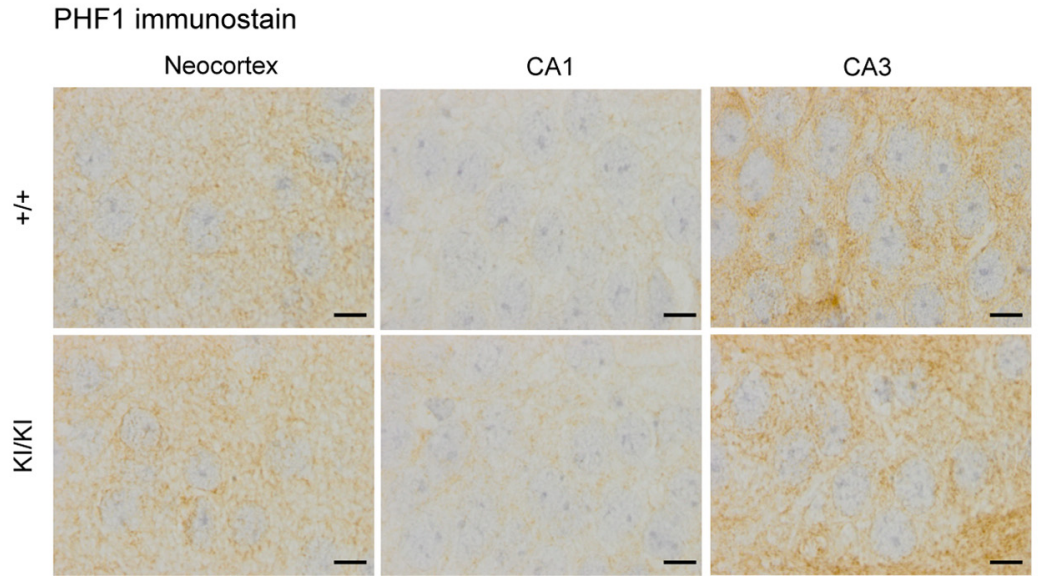

Figure 6. The Psen 1 c.548G $>T$ allele does not cause tau pathology in $\mathrm{KI} / \mathrm{KI}$ mice. $\mathrm{A}$, Phosphorylation status of tau protein in $\mathrm{KI} / \mathrm{KI}$ cerebral cortices. Total cortical protein lysates were subject to Western analysis for phosphorylated tau (PHF1 and (P13) and total tau. The signals of phosphorylated tau were divided by those of total tau. $\boldsymbol{B}$, The representative photos of immunohistochemistry for phospho-tau (PHF1). There is no significant change of tau phosphorylation in the neocortex and hippocampal areas CA1 and CA3. Scale bar, $10 \mu \mathrm{m}$. NS, Not significant. All data are expressed as mean \pm SEM.

disrupts proper splicing of a portion of the Psen 1 transcripts, resulting in the generation of aberrantly spliced products harboring premature termination codons, which were rapidly degraded by NMD mechanisms, leading to a consequent $\sim 40 \%$ decrease in the expression of full-length Psen 1 mRNAs in KI/KI brains.

\section{The reduction of Psen 1 mRNAs in $c .548 G>T$ KI mice is brain specific}

PS1 is ubiquitously expressed in many tissues (Lee et al., 1996), and reduced Psen dosage has been associated with skin disorders in humans and mice (Xia et al., 2001; Tournoy et al., 2004; Kelleher and Shen, 2010; Wang et al., 2010; Pink et al., 2011). But in FTD patients, the $c .548 G>T$ mutation gives rise to a brainspecific phenotype with no clinical remarks in other tissues (Dermaut et al., 2004). We therefore examined whether the $c .548 G>T$ mutation affects $P$ sen 1 splicing and expression in non-neural tissues. Interestingly, RT-PCR showed no evidence of aberrant splicing in the liver, lung, and skin of KI/KI mice, whereas the aberrantly spliced mRNAs were readily detected in the neocortex, hippocampus, and cerebellum (Fig. 4A). As a result, levels of Psen 1 mRNAs are unaltered in the liver, lung, and skin, as shown by quantitative RT-PCR (Fig. $4 B$ ). Additionally, we also examined expression levels of Psen 1 mRNAs in splenocytes, which contain broad spectrums of lymphocyte cell lineages, because Notch, a substrate of $\gamma$-secretase, is involved in regulation of lymphocyte cell development (Pui et al., 1999; Radtke et al., 1999). Northern analysis showed that expression levels of Psen 1 mRNAs are not changed in splenocytes in $\mathrm{KI} / \mathrm{KI}$ mice (data not shown). Moreover, cycloheximide treatment results in an accumulation of aberrantly spliced Psen 1 transcripts in the brain but not in the liver of c.548G $>T^{K I / K I}$ mice (Fig. $4 C$ ). These results demonstrate that the $c .548 G>T$ mutation causes aberrant splicing and subsequent reduction of Psen 1 expression only in the brain but not in non-neural tissues.

\section{Decreases of $\gamma$-secretase activities in the brain of $c .548 G>T$ KI mice}

To determine the effect of the $c .548 G>T$ mutation on $\gamma$-secretase activity, we performed in vitro $\gamma$-secretase assays using detergent-solubilized cerebral cortical fractions as the sensitive, direct method (Takahashi et al., 2003). Using CHAPSOsolubilized fractions from the cerebral cortex of c.548G $>T^{K I / K I}, c .548 G>T^{K I /+}$, and wild-type littermate control mice at 2-3 months of age, we found that $\gamma$-secretase activity is reduced in $\mathrm{KI} /+$ mice and further decreased in KI/KI mice, as measured by de novo production of Notch intracellular domain (NICD) from recombinant N102-FmH (substrates of NICD) (Fig. 5A). Production of NICD was abolished by a specific $\gamma$-secretase inhibitor, III-31C (Fig. 5A).

APP is the other well established physiological substrate of $\gamma$-secretase and $\gamma$-secretase-mediated cleavages give rise to $A \beta 40$ and $A \beta 42$ peptides (De Strooper et al., 1998). We then performed the same in vitro $\gamma$-secretase assay using CHAPSOsolubilized cortical fractions of $c .548 G>T^{K I / K I}, c .548 G>T^{K I /+}$, and wild-type mice, and found that de novo generation of $\mathrm{A} \beta \mathrm{x}-40$ and $\mathrm{A} \beta \mathrm{x}-42$ is drastically reduced in $\mathrm{KI}$ mice depending on the KI allele dosage (Fig. 5B). As a control, we also used cortices of Psen 1 conditional $\mathrm{KO}(\mathrm{cKO})$ mice, and, similar to our prior finding $(\mathrm{Yu}$ et al., 2001), de novo generation of $\mathrm{A} \beta \mathrm{x}-40$ and $\mathrm{A} \beta \mathrm{x}-42$ is robustly reduced in Psen $1 \mathrm{cKO}$ mice (Fig. 5B). In addition, we confirmed a decrease of de novo generation of total $\mathrm{A} \beta$ by Western blot (data not shown). We further performed sandwich ELISA to measure steady-state levels of endogenous $\mathrm{A} \beta$ peptides. Interestingly, measurement of the peptides showed decreased levels of $A \beta 40$ but unchanged levels of $\mathrm{A} \beta 42$ in the cerebral cortex of c.548G $>T^{K I / K I}$ mice at 12 months of age (Fig. $5 C$ ). The difference between de novo $\mathrm{A} \beta$ production and steady-state $\mathrm{A} \beta$ levels is likely due to the effect of $A \beta$ turnover in vivo (Wang et al., 2006).

Although the reduction of $\gamma$-secretase activities in $c .548 G>T$ $\mathrm{KI}$ mice is consistent with decreased Psen $1 \mathrm{mRNA}$ levels in these mice, the $c .548 G>T$ mutation also results in a substitution of glycine with valine at amino acid residue 183 . To determine whether the p.183G $>V$ conversion itself alters $\gamma$-secretase activity, we transfected vectors expressing either wild-type at varying amounts $(1 \times, 2 \times, 0.5 \times)$ or various mutant Psen $1 \mathrm{cDNAs}(1 \times)$ and truncated Notch1 (N $\Delta \mathrm{E}$ ) into Psen-deficient MEFs (Herreman et al., 
2000). One day after the transfection, we collected cell lysates and performed Western analysis. Wild-type and p.183G $>$ V PS1 displayed similar levels of $\gamma$-secretase activity, as measured by production of NICD, whereas PS1 bearing a p.257D $>$ A substitution, which abolishes $\gamma$-secretase activity, was unable to produce detectable NICD (Fig. 5D). The Psen1 mutant cDNA lacking exons 6 and 7 was similarly devoid of $\gamma$-secretase activity (Fig. 5D). These results suggest that full-length PS1 harboring the p.183G $>V$ alteration has normal $\gamma$-secretase activity; thus, this change is unlikely to be pathogenic. Collectively, these results suggest that the pathogenic effect of the $c .548 G>T$ mutation is a consequence of the brain-specific reduction in Psen 1 mRNA expression.

\section{Absence of tau pathology in the brain of c.548G $>T$ KI mice}

In addition to cerebral atrophy, FTD is sometimes associated neuropathologically with tau pathology (Neary et al., 2005). Neuropathological analysis of the patient carrying the PSEN1 c.548G $>$ T mutation revealed Pick's body and phosphorylated tau staining, in addition to severe frontotemporal atrophy and clear neuronal loss (Dermaut et al., 2004). Therefore, we next examined whether levels of tau and phosphorylated status are elevated in the cerebral cortex of KI/KI mice. Western analysis using rabbit polyclonal antibody for total tau showed similar levels of tau in the hippocampus and the neocortex between $\mathrm{KI} / \mathrm{KI}$ and wild-type littermate mice (Fig. $6 A$ and data not shown). Using monoclonal antibodies PHF1 (specific for phosphorylated Ser396/Ser404) and CP13 (specific for phosphorylated Ser202/Thr205), we found no significant changes phospho-tau in the neocortex and hippocampus of KI/KI mice (Fig. 6A). Immunohistochemical analysis using PHF1 antibodies further confirmed similar levels of phospho-tau in the neocortex and hippocampal areas CA1 and CA3 regions of KI/KI mice compared with littermate controls at 20 months of age (Fig. $6 B$ ). These results show that the Psen 1 c.548G $>$ T mutation does not cause tau pathology in mice, which may be due to the subtle effect of the mutation and the short lifespan of mice.

\section{Mild spatial memory impairment of c.548G $>$ T KI mice in the Psen $2^{-/-}$ background}

We previously reported that loss of presenilin function in the postnatal cerebral cortex impairs learning and memory in a gene dosage-dependent manner ( $\mathrm{Yu}$ et
A

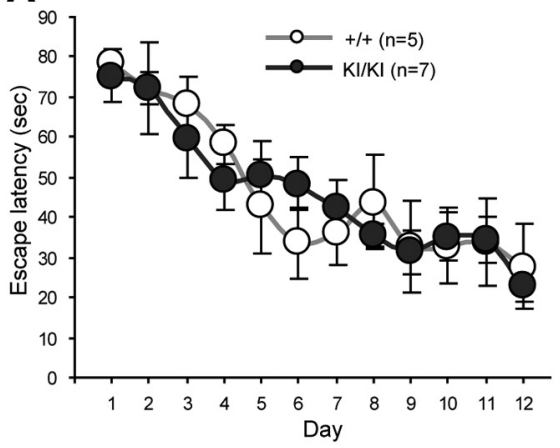

C probe test

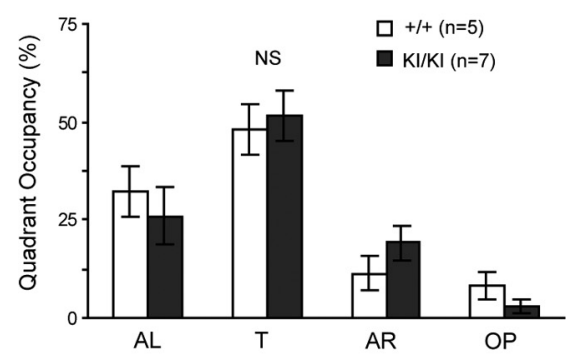

$E$

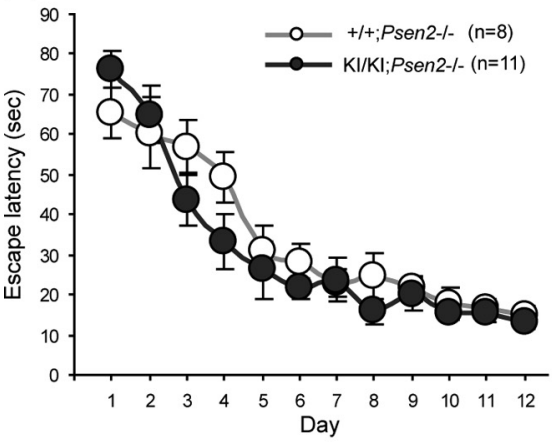

G

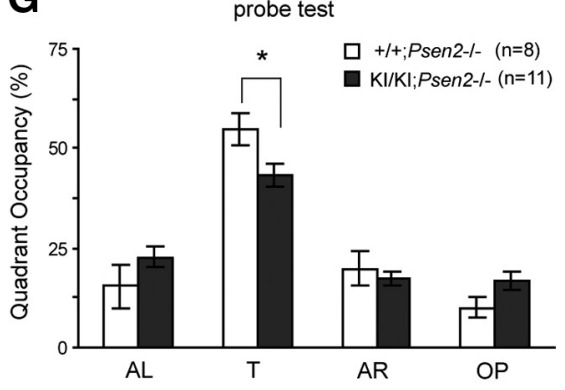

B

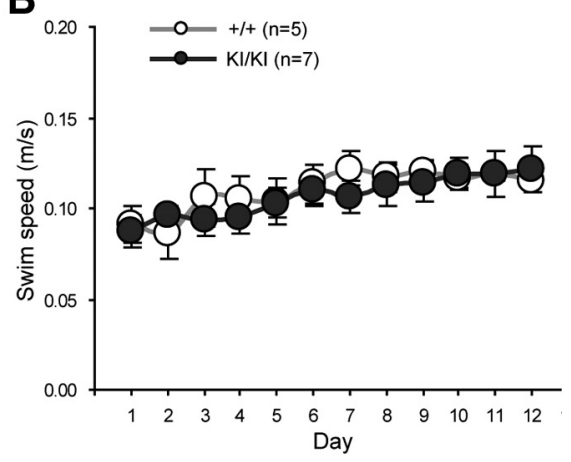

D

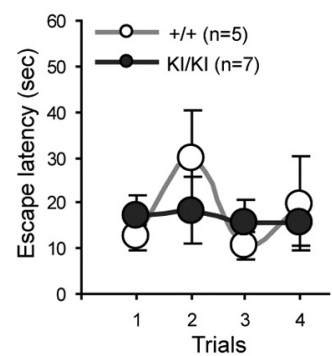

$\mathbf{F}$

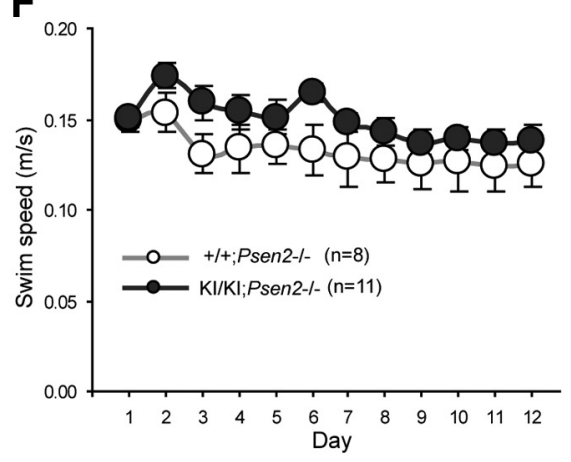

H

visible cue

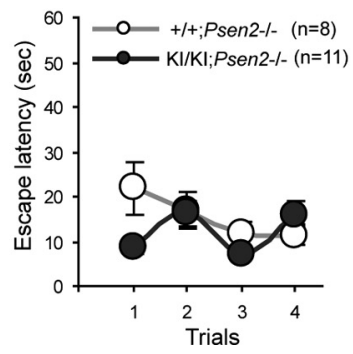

Figure 7. The Psen 1 c.548G $>T \mathrm{KI} / \mathrm{KI}$ mice in the Psen2-null background exhibit mild spatial memory impairment. $\boldsymbol{A}-\boldsymbol{D}$, Psen 1 c.548G $>T^{K / K I}$ and littermate wild-type control mice at $18-20$ months of age were subjected to training in the hidden platform water maze for $12 \mathrm{~d}$ (four trials a day) followed by four trials of training in the visible platform version of the task. The escape latency $(\boldsymbol{A})$ and swimming speed $(\boldsymbol{B})$ of $\mathrm{KI} / \mathrm{KI}$ mice $(n=5)$ are similar to that of littermate controls $(n=7)$ during the $12 \mathrm{~d}$ training phase of the hidden platform water maze task. C, KI/KI and littermate control mice also displayed similar quadrant occupancy in the post-training probe trial administered $24 \mathrm{~h}$ after the final training session. $\boldsymbol{D}$. The escape latency in the visible platform version of the task is normal in $\mathrm{KI} / \mathrm{KI}$ mice. $\boldsymbol{E}-\boldsymbol{H}, P \operatorname{sen} 1$ c.548G $>T^{K I / K I}, P \operatorname{Psen} 2^{-I-}$ and littermate control mice at $6-8$ months of age were subjected to training in the hidden platform water maze for $12 \mathrm{~d}$ (four trials a day) followed by four trials of training in the visible platform version of the task. $\boldsymbol{E}, \boldsymbol{F}$, The escape latency $(F=0.032 ; \mathrm{df}=1,17 ; p=0.8601)$ and swimming speed $(F=3.549 ; \mathrm{df}=$ $1,17 ; p=0.0768)$ of $P \operatorname{sen} 1 c .548 G>T^{K / K I}, P$ sen2 $2^{-I-}$ mice $(n=11)$ are similar as littermate controls $(n=8)$ during the $12 \mathrm{~d}$ training phase in the hidden platform. $G$, However, during the probe trial $24 \mathrm{~h}$ after the final training session at day 12, Psen 1 c.548G $>T^{K / K I} ;$ Psen $2^{-1-}$ mice show significant reduction in quadrant occunpancy $(p=0.0267)$, suggesting mild impairment of spatial memory. $\boldsymbol{H}, P_{s e n} 1 c .548 G>T^{K I / K I}, P$ sen $2^{-I-}$ mice performed normally in the visible cue task. AL, Adjacent left quadrant; $\mathrm{T}$, target quadrant; $\mathrm{AR}$, adjacent right quadrant; $\mathrm{OP}$, opposite quadrant. All data are expressed as mean $\pm \mathrm{SEM}$. ${ }^{*} p<0.05$. 
Psen1 c. 548G >T allele

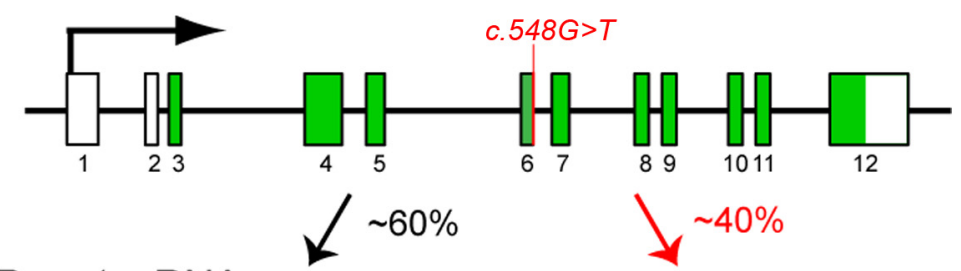

Psen1 mRNAs full-length

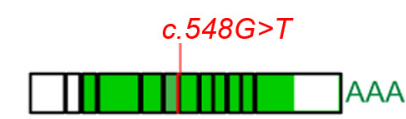
$A A$

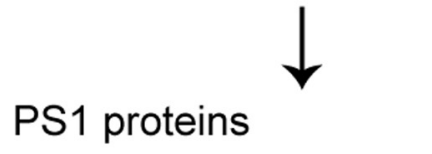

sexons6-7

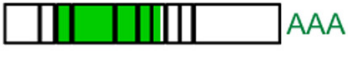

$\Delta$ exon6

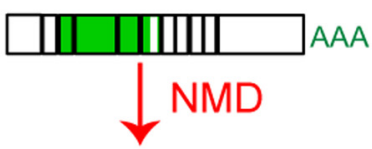

mRNA degradation

(Normal $\gamma$-secretase activity)

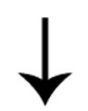

\section{$\downarrow$ Level of PS1 expression $\downarrow$ Presenilin function}

Figure 8. A schematic model for the effect of the $P$ sen 1 c.548G $>$ T mutation on presenilin expression and function in the mouse brain. The c.548G $>$ T mutation causes exon skipping in $\sim 40 \%$ of Psen 1 transcripts, which were degraded by non-sense-mediated decay mechanisms. The remaining $\sim 60 \%$ Psen 1 transcripts were spliced properly into full-length Psen 1 c.548G $>T$ mRNAs, producing PS1 proteins containing the p.183G $>V$ variant, which exhibit normal $\gamma$-secretase activity. Thus, the net effect of the c.548G $>$ T mutation is purely a $\sim 40 \%$ reduction of Psen $1 \mathrm{mRNA}$ expression in the brain, which subsequently decreases presenilin function in the regulation of $\gamma$-secretase activity and cognition. The boxes denote Psen 1 exons 1-12, and the green areas correspond to coding sequences. The c.548G $>T$ mutation shown in red resides at the exon 6 and intron 6 boundary. The blue areas in PS1 protein depict transmembrane domains.

al., 2001; Saura et al., 2004). Whereas Psen $2^{-1-}$ mice exhibited normal learning and memory, conditional inactivation of Psen 1 and $P \operatorname{sen} 1 / 2$ in postnatal cerebral cortex caused mild and severe memory deficits, respectively. To determine whether the c.548G $>$ T mutation impairs presenilin function in cognition, we tested hippocampus-dependent spatial learning and memory using the Morris water maze task. Psen 1 c.548G $>T^{K I / K I}$ and wildtype littermate control mice were given four trials a day for $12 \mathrm{~d}$, and they performed similarly during the $12 \mathrm{~d}$ learning phase (Fig. $7 A, B$, latency and swim speed) and in the probe trial $24 \mathrm{~h}$ after the final training session (Fig. $7 C$, quadrant occupancy). Psen1 c.548G $>T^{K I / K I}$ mice also did not show any deficit in the visible cue task (Fig. 7D). We next examined Psen 1 c.548G $>T^{K I / K I}$ and littermate control mice in the Psen2-null background, because Psen 1 cKO mice exhibit more severe learning and memory deficits in the absence of PS2 compensation (Saura et al., 2004). During the $12 \mathrm{~d}$ training phase, ANOVA did not show a significant genotype effect in escape latency (Fig. $7 E)(F=0.709 ; \mathrm{df}=$ $1,17 ; p=0.4114)$, path length $(F=0.032 ; \mathrm{df}=1,17 ; p=0.8601)$, and swim speed (Fig. $7 F)(F=3.549 ; \mathrm{df}=1,17 ; p=0.0768)$, but Psen1 c.548G $>T^{K I / K I} ;$ Psen $2^{-/-}$mice exhibited significantly lower quadrant occupancy during the probe trial administered $24 \mathrm{~h}$ after the last training session (Fig. 7G; $p<0.05$ ), suggesting mild spatial memory impairment. The Psen 1 c.548G $>T^{K I / K I} ;$ Psen $2^{-/-}$mice performed normally in the visible cue task (Fig. $7 H$ ). These results suggest that the Psen 1 c.548G $>$ T mutation causes a functional impairment of presenilin activity in cognition, likely due to reduction of Psen 1 expression.

\section{Discussion}

Presenilin comprises the catalytic component of the aspartate protease complex $\gamma$-secretase, which plays essential roles during embryonic development (Shen et al., 1997; Wong et al., 1997; Donoviel et al., 1999; Li et al., 2000). The $\gamma$-secretase complex, which also includes nicastrin, Aph-1, and Pen-2 (Yu et al., 2000; Francis et al., 2002; Goutte et al., 2002), is involved in the intramembrane cleavage of type I transmembrane proteins such as APP and Notch (De Strooper et al., 1998, 1999). Presenilin is broadly expressed in the brain but mediate unique functions in specific cell types (Lee et al., 1996; Handler et al., 2000; Saura et al., 2004; WinesSamuelson et al., 2005, 2010; Kim and Shen, 2008; Zhang et al., 2009). Importantly, we previously showed that selective inactivation of PS in the adult cerebral cortex causes progressive memory impairment followed by age-dependent neurodegeneration in the absence of increases of $\beta$-amyloid peptides (Beglopoulos et al., 2004; Saura et al., 2004; Wines-Samuelson et al., 2010). Although these studies support the view that loss of PS function contributes to neurodegeneration and dementia, how PSEN mutations affect its function and lead to AD and FTD remains to be determined.

In this study, we generated a novel KI mouse model carrying the FTD-associated PSEN1 c.548G $>$ T mutation to investigate the underlying pathogenic mechanism and to explore the molecular link between the roles of PSEN mutations in AD and FTD. Unexpectedly, we discovered that the $c .548 G>T$ mutation reduces expression of full-length Psen 1 mRNAs as a result of aberrant splicing and NMD-mediated degradation of improper splice products (Figs. 2, 3), and that the corresponding p.183G $>V$ change in the protein sequence does not affect PS function in $\gamma$-secretase activity (Fig. 5). Consistent with this reduction in Psen 1 expression, $c .548 G>T^{K I / K I}$ brains exhibit reduced $\gamma$-secretase activity and mild learning and memory deficits (Figs. 5, 7). Surprisingly, the aberrant splicing and decreased Psen 1 expression elicited by the $c .548 G>T$ mutation are brain specific, illuminating a mechanism by which Psen 1 mutations can produce brain-specific phenotypes in FTD patients (Fig. 4). Collectively, our genetic study shows that the FTD-associated PSEN1 c.548G $>$ T mutation causes a net loss of presenilin activity due to reduced $P \operatorname{sen} 1$ mRNA expression (Fig. 8).

Interestingly, aberrant splicing of PSEN1 transcripts and abnormal PS1 protein expression has previously been reported in cases of sporadic FTD (Evin et al., 2002). Moreover, PSEN1 mu- 
tations identified in other FTD pedigrees also reside at exonintron boundaries, possibly leading to splicing defects (Raux et al., 2000; Borroni et al., 2011). Thus, failure of proper PSEN1 mRNA splicing and consequent reduction of PS1 expression could represent a common mechanism underlying both sporadic and familial FTD. Supporting the plausibility of such a mechanism in FTD pathogenesis, it has been estimated that $\sim 15 \%$ of all point mutations causing human genetic disease result in an mRNA splicing defect (Krawczak et al., 1992; Liu et al., 2001).

Another intriguing discovery of our study is the brain specificity of the splicing defect caused by the $c .548 G>T$ mutation, sparing other tissues from detrimental effects associated with reduced PSEN1 expression. Recent studies have shown an association between haploinsufficiency of $\gamma$-secretase component proteins and familial acne inversa (Kelleher and Shen, 2010; Wang et al., 2010; Li et al., 2011; Pink et al., 2011). However, our molecular analysis of $c .548 G>T$ KI mice showed that levels of Psen 1 mRNAs are only reduced in the brain (Fig. 4). Further analysis revealed that aberrant splicing and subsequent degradation of transcripts from the $c .548 G>T$ KI allele occur only in the brain but not in other tissues. The detailed molecular mechanism by which aberrant splice products are produced in a brainspecific manner remains to be determined. One possible explanation could be the existence of brain-specific alternative splicing factors (Dredge et al., 2001). A brain-restricted expression of a specific splicing factors might render the splicing machinery less tolerant of the $\mathrm{G}>\mathrm{T}$ transversion at the splice donor site, leading to skipping of this exon only in the brain.

While the effect of the c.548G $>$ T mutation on the overall level of Psen 1 mRNAs is modest, its effect on $\gamma$-secretase activity measured by de novo production of NICD or $\mathrm{A} \beta$ peptides in KI brains is surprisingly robust (Fig. 5). For example, the production of A $\beta 40$ peptides in $c .548 G>T^{K I / K I}$ brains is reduced by $\sim 70 \%$. These results indicate that $\gamma$-secretase activity is very sensitive to changes in presenilin dosage, suggesting that small reductions of presenilin expression may be sufficient to produce substantial deficits in its essential functions (e.g., at the synapse). However, in vivo steady-state levels of $\mathrm{A} \beta$ peptides are less affected (Fig. 5), suggesting that a compensatory reduction in $\mathrm{A} \beta$ turnover may accompany the reduced $\mathrm{A} \beta$ production in KI mice. Consistent with our earlier findings (Yu et al., 2001; Saura et al., 2004), we found that Psen 1 c.548G $>T^{K I / K I}$ mice in the Psen2-null background exhibit mild deficits in spatial learning and memory (Fig. 7). Not surprisingly, the spatial memory deficits exhibited by Psen1 c.548G $>T^{K I / K I} ; P_{s e n} 2^{-/-}$mice was subtler than those of Psen 1 cKO mice, in which PS1 is completely inactivated in excitatory neurons of the adult cerebral cortex, whereas Psen conditional double-knock-out mice exhibit more dramatic memory impairment (Yu et al., 2001; Saura et al., 2004).

It has been long debated whether PSEN mutations cause a toxic gain of function or a loss of essential functions normally performed by presenilin (Shen and Kelleher, 2007). PSEN mutations associated with familial $\mathrm{AD}$ often lead to selective increases of the longer and more amyloidogenic $\mathrm{A} \beta 42$ peptides, which has been taken as evidence for the toxic gain-of-function mechanism. However, shortly after the identification of the PSEN mutations in familial $\mathrm{AD}$, such mutations were found to reduce its biological function and $\gamma$-secretase activity in invertebrate models and cell culture systems (Levitan et al., 1996; Song et al., 1999; Seidner et al., 2006). More recently, a clinical PSEN1 mutation conferring a complete loss of PS1 function and $\gamma$-secretase activity has been described (Heilig et al., 2010). These findings are consistent with our prior work showing that complete inactivation of presenilin function in the adult mouse brain causes dementia and progressive neurodegeneration, two key features common to $\mathrm{AD}$ and FTD (Saura et al., 2004; Wines-Samuelson et al., 2010). Thus, impairment of essential PS functions in neuronal survival and memory may be a common property of PSEN mutations in both of these neurodegenerative dementias.

Our findings demonstrate that the FTD-associated c.548G $>T$ mutation decreases Psen $1 \mathrm{mRNA}$ expression, leading to a partial loss of presenilin and $\gamma$-secretase function. However, the amino acid substitution derived from the $c .548 \mathrm{G}>T$ mutation p.183G $>\mathrm{V}$ does not affect $\gamma$-secretase activity. Thus, the net effect of the $c .548 G>T$ mutation is limited to the reduction of Psen $1 \mathrm{mRNA}$ and protein expression, indicating that a pure loss of PSEN expression is pathogenic. This loss of PS expression without altered PS protein activity offers a possible mechanism to account for the development of neurodegeneration and dementia in the absence of $\mathrm{A} \beta$ deposition in FTD. It is presently unclear whether other PSEN mutations that have been associated with FTD also affect PS expression, although the localization of some FTD-associated PSEN mutations at splice junctions (e.g., c.1129A $>T, c .338 T>C$ ) raises the possibility that similar mechanisms may be at play (Ikeda et al., 1996; Raux et al., 2000; Binetti et al., 2003; Portet et al., 2003; Rippon et al., 2003; Halliday et al., 2005; Zekanowski et al., 2006; Bernardi et al., 2009; de Bot et al., 2009; Marcon et al., 2009; Gallo et al., 2010; Borroni et al., 2011). Future studies will be needed to determine the effects on presenilin function and $\gamma$-secretase activity of other FTD-associated PSEN mutations, which include mutations situated at the splice consensus sites [PSEN1: c.1129A $>$ T (p.377R $>\mathrm{W})$ and c.338T $>C$ (p.113L $>P$ ) ] and mutations whose localization suggests simple missense substitution (e.g., PSEN1: p.139M $>$ V, p. $146 \mathrm{M}>\mathrm{L}$, p.226L $>$ F, p. $233 \mathrm{M}>$ L, p. $260 \mathrm{~A}>\mathrm{V}$, p. $412 \mathrm{~V}>\mathrm{I}, \mathrm{p} .424 \mathrm{~L}>\mathrm{H}, \mathrm{p} .424 \mathrm{~L}>\mathrm{R}$; PSEN2: p.62R $>$ H, p. $122 \mathrm{~T}>\mathrm{R}, \mathrm{p} .231 \mathrm{Y}>\mathrm{C}, \mathrm{p} .239 \mathrm{M}>\mathrm{V}$ ). These studies may help us understand why some of the same PSEN1 mutations are associated with patients who were initially diagnosed clinically as $\mathrm{AD}$ or FTD (Ikeda et al., 1996; Portet et al., 2003; Rippon et al., 2003; Halliday et al., 2005; Zekanowski et al., 2006). Our findings imply that transgenic approaches in cell culture or mice may not provide a complete picture of the impact of PSEN mutations on PS function and $\gamma$-secretase activity; rather, analysis of PSEN mutations in the context of the genomic locus will be important to evaluate potential effects on mRNA splicing and post-transcriptional regulation of PSEN expression. Whether the pure loss of PSEN expression identified in this study constitutes a common pathogenic mechanism by which PSEN mutations cause FTD remains to be determined.

\section{References}

Beglopoulos V, Sun X, Saura CA, Lemere CA, Kim RD, Shen J (2004) Reduced beta-amyloid production and increased inflammatory responses in presenilin conditional knock-out mice. J Biol Chem 279:46907-46914.

Bernardi L, Tomaino C, Anfossi M, Gallo M, Geracitano S, Costanzo A, Colao R, Puccio G, Frangipane F, Curcio SA, Mirabelli M, Smirne N, Iapaolo D, Maletta RG, Bruni AC (2009) Novel PSEN1 and PGRN mutations in early-onset familial frontotemporal dementia. Neurobiol Aging 30:1825-1833.

Binetti G, Signorini S, Squitti R, Alberici A, Benussi L, Cassetta E, Frisoni GB, Barbiero L, Feudatari E, Nicosia F, Testa C, Zanetti O, Gennarelli M, Perani D, Anchisi D, Ghidoni R, Rossini PM (2003) Atypical dementia associated with a novel presenilin-2 mutation. Ann Neurol 54:832-836.

Borroni B, Pilotto A, Bonvicini C, Archetti S, Alberici A, Lupi A, Gennarelli M, Padovani A (2011) Atypical presentation of a novel Presenilin 1 R377W mutation: sporadic, late-onset Alzheimer disease with epilepsy and frontotemporal atrophy. Neurol Sci. Advance online publication. Retrieved August 6, 2011. doi:10.1007/s10072-011-0714-1.

Cartegni L, Chew SL, Krainer AR (2002) Listening to silence and understanding nonsense: exonic mutations that affect splicing. Nat Rev Genet 3:285-298. 
Contet C, Dierich A, Kieffer BL (2007) Knock-in mice reveal nonsensemediated mRNA decay in the brain. Genesis 45:38-43.

de Bot ST, Kremer HP, Dooijes D, Verbeek MM (2009) CSF studies facilitate DNA diagnosis in familial Alzheimer's disease due to a presenilin-1 mutation. J Alzheimers Dis 17:53-57.

Dermaut B, Kumar-Singh S, Engelborghs S, Theuns J, Rademakers R, Saerens J, Pickut BA, Peeters K, van den Broeck M, Vennekens K, Claes S, Cruts M, Cras P, Martin JJ, Van Broeckhoven C, De Deyn PP (2004) A novel presenilin 1 mutation associated with Pick's disease but not beta-amyloid plaques. Ann Neurol 55:617-626.

De Strooper B, Saftig P, Craessaerts K, Vanderstichele H, Guhde G, Annaert W, Von Figura K, Van Leuven F (1998) Deficiency of presenilin-1 inhibits the normal cleavage of amyloid precursor protein. Nature 391:387-390.

De Strooper B, Annaert W, Cupers P, Saftig P, Craessaerts K, Mumm JS, Schroeter EH, Schrijvers V, Wolfe MS, Ray WJ, Goate A, Kopan R (1999) A presenilin-1-dependent gamma-secretase-like protease mediates release of Notch intracellular domain. Nature 398:518-522.

Donoviel DB, Hadjantonakis AK, Ikeda M, Zheng H, Hyslop PS, Bernstein A (1999) Mice lacking both presenilin genes exhibit early embryonic patterning defects. Genes Dev 13:2801-2810.

Dredge BK, Polydorides AD, Darnell RB (2001) The splice of life: alternative splicing and neurological disease. Nat Rev Neurosci 2:43-50.

Evin G, Smith MJ, Tziotis A, McLean C, Canterford L, Sharples RA, Cappai R, Weidemann A, Beyreuther K, Cotton RG, Masters CL, Culvenor JG (2002) Alternative transcripts of presenilin-1 associated with frontotemporal dementia. Neuroreport 13:917-921.

Francis R, McGrath G, Zhang J, Ruddy DA, Sym M, Apfeld J, Nicoll M, Maxwell M, Hai B, Ellis MC, Parks AL, Xu W, Li J, Gurney M, Myers RL, Himes CS, Hiebsch R, Ruble C, Nye JS, Curtis D (2002) aph-1 and pen-2 are required for Notch pathway signaling, gamma-secretase cleavage of betaAPP, and presenilin protein accumulation. Dev Cell 3:85-97.

Galimberti D, Scarpini E (2010) Genetics and biology of Alzheimer's disease and frontotemporal lobar degeneration. Int J Clin Exp Med 3:129-143.

Gallo M, Tomaino C, Puccio G, Frangipane F, Curcio SA, Bernardi L, Geracitano S, Anfossi M, Mirabelli M, Colao R, Vasso F, Smirne N, Maletta RG, Bruni AC (2010) Novel MAPT Val75Ala mutation and PSEN2 Arg62Hys in two siblings with frontotemporal dementia. Neurol Sci 31:65-70.

Goutte C, Tsunozaki M, Hale VA, Priess JR (2002) APH-1 is a multipass membrane protein essential for the Notch signaling pathway in Caenorhabditis elegans embryos. Proc Natl Acad Sci U S A 99:775-779.

Halliday GM, Song YJ, Lepar G, Brooks WS, Kwok JB, Kersaitis C, Gregory G, Shepherd CE, Rahimi F, Schofield PR, Kril JJ (2005) Pick bodies in a family with presenilin-1 Alzheimer's disease. Ann Neurol 57:139-143.

Handler M, Yang X, Shen J (2000) Presenilin-1 regulates neuronal differentiation during neurogenesis. Development 127:2593-2606.

Heilig EA, Xia W, Shen J, Kelleher RJ 3rd (2010) A presenilin-1 mutation identified in familial Alzheimer disease with cotton wool plaques causes a nearly complete loss of gamma-secretase activity. J Biol Chem 285:22350-22359.

Herreman A, Serneels L, Annaert W, Collen D, Schoonjans L, De Strooper B (2000) Total inactivation of gamma-secretase activity in presenilindeficient embryonic stem cells. Nat Cell Biol 2:461-462.

Ignotz GG, Suarez SS (2005) Calcium/calmodulin and calmodulin kinase II stimulate hyperactivation in demembranated bovine sperm. Biol Reprod 73:519-526.

Ikeda M, Sharma V, Sumi SM, Rogaeva EA, Poorkaj P, Sherrington R, Nee L, Tsuda T, Oda N, Watanabe M, Aoki M, Shoji M, Abe K, Itoyama Y, Hirai S, Schellenberg GD, Bird TD, St George-Hyslop PH (1996) The clinical phenotype of two missense mutations in the presenilin I gene in Japanese patients. Ann Neurol 40:912-917.

Kelleher RJ 3rd, Shen J (2010) Genetics. Gamma-secretase and human disease. Science 330:1055-1056.

Kim WY, Shen J (2008) Presenilins are required for maintenance of neural stem cells in the developing brain. Mol Neurodegener 3:2.

Krawczak M, Reiss J, Cooper DN (1992) The mutational spectrum of single base-pair substitutions in mRNA splice junctions of human genes: causes and consequences. Hum Genet 90:41-54.

Lee MK, Slunt HH, Martin LJ, Thinakaran G, Kim G, Gandy SE, Seeger M, Koo E, Price DL, Sisodia SS (1996) Expression of presenilin 1 and 2 (PS1 and PS2) in human and murine tissues. J Neurosci 16:7513-7525.
Lee MK, Borchelt DR, Kim G, Thinakaran G, Slunt HH, Ratovitski T, Martin LJ, Kittur A, Gandy S, Levey AI, Jenkins N, Copeland N, Price DL, Sisodia SS (1997) Hyperaccumulation of FAD-linked presenilin 1 variants in vivo. Nat Med 3:756-760.

Levitan D, Doyle TG, Brousseau D, Lee MK, Thinakaran G, Slunt HH, Sisodia SS, Greenwald I (1996) Assessment of normal and mutant human presenilin function in Caenorhabditis elegans. Proc Natl Acad Sci U S A 93:14940-14944.

Li CR, Jiang MJ, Shen DB, Xu HX, Wang HS, Yao X, Zhang Y, Zhou WQ, Wang B (2011) Two novel mutations of the nicastrin gene in Chinese patients with acne inversa. Br J Dermatol 165:415-418.

Li YM, Xu M, Lai MT, Huang Q, Castro JL, DiMuzio-Mower J, Harrison T, Lellis C, Nadin A, Neduvelil JG, Register RB, Sardana MK, Shearman MS, Smith AL, Shi XP, Yin KC, Shafer JA, Gardell SJ (2000) Photoactivated gamma-secretase inhibitors directed to the active site covalently label presenilin 1. Nature 405:689-694.

Liu HX, Cartegni L, Zhang MQ, Krainer AR (2001) A mechanism for exon skipping caused by nonsense or missense mutations in BRCA1 and other genes. Nat Genet 27:55-58.

Marcon G, Di Fede G, Giaccone G, Rossi G, Giovagnoli AR, Maccagnano E, Tagliavini F (2009) A novel Italian presenilin 2 gene mutation with prevalent behavioral phenotype. J Alzheimers Dis 16:509-511.

Mendez MF, McMurtray A (2006) Frontotemporal dementia-like phenotypes associated with presenilin-1 mutations. Am J Alzheimers Dis Other Demen 21:281-286.

Neary D, Snowden J, Mann D (2005) Frontotemporal dementia. Lancet Neurol 4:771-780.

Pink AE, Simpson MA, Brice GW, Smith CH, Desai N, Mortimer PS, Barker JN, Trembath RC (2011) PSENEN and NCSTN mutations in familial hidradenitis suppurativa (Acne Inversa). J Invest Dermatol 131:1568-1570.

Portet F, Dauvilliers Y, Campion D, Raux G, Hauw JJ, Lyon-Caen O, Camu W, Touchon J (2003) Very early onset AD with a de novo mutation in the presenilin 1 gene (Met $233 \mathrm{Leu}$ ). Neurology 61:1136-1137.

Pui JC, Allman D, Xu L, DeRocco S, Karnell FG, Bakkour S, Lee JY, Kadesch T, Hardy RR, Aster JC, Pear WS (1999) Notch1 expression in early lymphopoiesis influences $\mathrm{B}$ versus $\mathrm{T}$ lineage determination. Immunity 11:299-308.

Radtke F, Wilson A, Stark G, Bauer M, van Meerwijk J, MacDonald HR, Aguet M (1999) Deficient $T$ cell fate specification in mice with an induced inactivation of Notch 1 . Immunity 10:547-558.

Raux G, Gantier R, Thomas-Anterion C, Boulliat J, Verpillat P, Hannequin D, Brice A, Frebourg T, Campion D (2000) Dementia with prominent frontotemporal features associated with L113P presenilin 1 mutation. Neurology 55:1577-1578.

Rippon GA, Crook R, Baker M, Halvorsen E, Chin S, Hutton M, Houlden H, Hardy J, Lynch T (2003) Presenilin 1 mutation in an african american family presenting with atypical Alzheimer dementia. Arch Neurol 60:884-888.

Saura CA, Choi SY, Beglopoulos V, Malkani S, Zhang D, Shankaranarayana Rao BS, Chattarji S, Kelleher RJ 3rd, Kandel ER, Duff K, Kirkwood A, Shen J (2004) Loss of presenilin function causes impairments of memory and synaptic plasticity followed by age-dependent neurodegeneration. Neuron 42:23-36.

Seidner GA, Ye Y, Faraday MM, Alvord WG, Fortini ME (2006) Modeling clinically heterogeneous presenilin mutations with transgenic Drosophila. Curr Biol 16:1026-1033.

Shen J, Bronson RT, Chen DF, Xia W, Selkoe DJ, Tonegawa S (1997) Skeletal and CNS defects in Presenilin-1-deficient mice. Cell 89:629-639.

Shen J, Kelleher RJ 3rd (2007) The presenilin hypothesis of Alzheimer's disease: evidence for a loss-of-function pathogenic mechanism. Proc Natl Acad Sci U S A 104:403-409.

Sjögren M, Andersen C (2006) Frontotemporal dementia-a brief review. Mech Ageing Dev 127:180-187.

Song W, Nadeau P, Yuan M, Yang X, Shen J, Yankner BA (1999) Proteolytic release and nuclear translocation of Notch-1 are induced by presenilin-1 and impaired by pathogenic presenilin-1 mutations. Proc Natl Acad Sci U S A 96:6959-6963.

Steiner H, Duff K, Capell A, Romig H, Grim MG, Lincoln S, Hardy J, Yu X, Picciano M, Fechteler K, Citron M, Kopan R, Pesold B, Keck S, Baader M, Tomita T, Iwatsubo T, Baumeister R, Haass C (1999) A loss of function 
mutation of presenilin-2 interferes with amyloid beta-peptide production and notch signaling. J Biol Chem 274:28669-28673.

Takahashi Y, Hayashi I, Tominari Y, Rikimaru K, Morohashi Y, Kan T, Natsugari H, Fukuyama T, Tomita T, Iwatsubo T (2003) Sulindac sulfide is a noncompetitive gamma-secretase inhibitor that preferentially reduces Abeta 42 generation. J Biol Chem 278:18664-18670.

Tournoy J, Bossuyt X, Snellinx A, Regent M, Garmyn M, Serneels L, Saftig P, Craessaerts K, De Strooper B, Hartmann D (2004) Partial loss of presenilins causes seborrheic keratosis and autoimmune disease in mice. Hum Mol Genet 13:1321-1331.

Wang B, Yang W, Wen W, Sun J, Su B, Liu B, Ma D, Lv D, Wen Y, Qu T, Chen M, Sun M, Shen Y, Zhang X (2010) Gamma-secretase gene mutations in familial acne inversa. Science 330:1065.

Wang R, Wang B, He W, Zheng H (2006) Wild-type presenilin 1 protects against Alzheimer disease mutation-induced amyloid pathology. J Biol Chem 281:15330-15336.

Wines-Samuelson M, Handler M, Shen J (2005) Role of presenilin-1 in cortical lamination and survival of Cajal-Retzius neurons. Dev Biol 277:332-346.

Wines-Samuelson M, Schulte EC, Smith MJ, Aoki C, Liu X, Kelleher RJ 3rd, Shen J (2010) Characterization of age-dependent and progressive cortical neuronal degeneration in presenilin conditional mutant mice. PLoS One 5:e10195.

Wong PC, Zheng H, Chen H, Becher MW, Sirinathsinghji DJ, Trumbauer ME, Chen HY, Price DL, Van der Ploeg LH, Sisodia SS (1997) Presenilin
1 is required for Notch 1 and DIIl expression in the paraxial mesoderm. Nature 387:288-292.

Xia X, Qian S, Soriano S, Wu Y, Fletcher AM, Wang XJ, Koo EH, Wu X, Zheng $H$ (2001) Loss of presenilin 1 is associated with enhanced beta-catenin signaling and skin tumorigenesis. Proc Natl Acad Sci U S A 98:10863-10868.

Yu G, Nishimura M, Arawaka S, Levitan D, Zhang L, Tandon A, Song YQ, Rogaeva E, Chen F, Kawarai T, Supala A, Levesque L, Yu H, Yang DS, Holmes E, Milman P, Liang Y, Zhang DM, Xu DH, Sato C, Rogaev E, Smith M, Janus C, Zhang Y, Aebersold R, Farrer LS, Sorbi S, Bruni A, Fraser P, St George-Hyslop P (2000) Nicastrin modulates presenilinmediated notch/glp-1 signal transduction and betaAPP processing. Nature 407:48-54.

Yu H, Saura CA, Choi SY, Sun LD, Yang X, Handler M, Kawarabayashi T, Younkin L, Fedeles B, Wilson MA, Younkin S, Kandel ER, Kirkwood A, Shen J (2001) APP processing and synaptic plasticity in presenilin-1 conditional knockout mice. Neuron 31:713-726.

Zekanowski C, Golan MP, Krzyśko KA, Lipczyńska-Lojkowska W, Filipek S, Kowalska A, Rossa G, Peplońska B, Styczyńska M, Maruszak A, Religa D, Wender M, Kulczycki J, Barcikowska M, Kuźnicki J (2006) Two novel presenilin 1 gene mutations connected with frontotemporal dementialike clinical phenotype: genetic and bioinformatic assessment. Exp Neurol 200:82-88.

Zhang C, Wu B, Beglopoulos V, Wines-Samuelson M, Zhang D, Dragatsis I, Südhof TC, Shen J (2009) Presenilins are essential for regulating neurotransmitter release. Nature 460:632-636. 